\title{
A Proposed Method to Evaluate Warehouse Location for 3PL Cold Chain Suppliers in Gulf Countries Using Neutrosophic Fuzzy EDAS
}

\author{
Murat Levent Demircan ${ }^{1}$ (D) $\cdot$ Berkay Özcan $^{2}$
}

Received: 30 October 2020 / Accepted: 2 November 2021

(c) The Author(s) 2021

\begin{abstract}
Logistics processes have been analyzed as one of the most critical expense items for companies. Companies that failed to manage their logistics processes well could not reach the desired growth rates, and some even disappeared. Logistics management without process optimizations can be time and money consuming for the companies. Logistics processes significantly influence organizations' efficiency. Logistic professionals should keep the process flow quality at a certain level, and some decision problems should be analyzed and answered well. Location selection of a warehouse is one of the most crucial decision problems of supply chain and logistics management. Alternatives are evaluated in quantitative and qualitative criteria to decide the best location alternative using scientific MCDM techniques. Different scientific methods have been developed and used to solve this problem. As for this study, the aim is to investigate the warehouse location selection of third-party cold chain logistics suppliers. The importance of keeping perishable products under the right conditions increased, since it is realized that cold chain warehousing and transportation prevent the product spoiled. Organizations can save their funds and time by having effective cold chain management. This study's main scope is to give a new scientific perspective for warehouse selection in cold chain logistics. MCDM technique of Interval-Valued Neutrosophic Fuzzy (IVNF) EDAS method has been used to evaluate essential criteria and choose the best option. Critical cities of Gulf Region countries have been considered alternatives in a numerical illustration.
\end{abstract}

Keywords Warehouse location selection · Multiple criteria decision-making · Fuzzy logic and systems · Interval-valued neutrosophic fuzzy EDAS method

\section{Introduction}

We all have a different kinds of needs during the day. These needs can be material, information, or money, and somehow they have to reach us. Therefore, somebody should provide or supply these needs to related ones or us. These providers can be a producer or can be a dealer. In such an ecosystem, good supply chain management is needed to ensure the correct integration of the elements. According to Mentzer et al., a supply chain can be evaluated as a group of entities with

Murat Levent Demircan

ldemircan@gsu.edu.tr

Berkay Özcan

berkayozcan92@gmail.com

1 Industrial Engineering Department, Galatasaray University, 34349 Ortaköy, Istanbul, Turkey

2 Ceva Logistics, Istabul, Turkey three or more members [1]. All these members are included in downstream or upstream flows of information, product, money, and services from the point of source to the customer's end.

Logistics processes play an essential role in the different supply chain stages. Logistics is the delivery of the right product; to the right place, with the right quantity, at the right time, with the minimum cost, with the maximum flexibility, as undamaged.

Logistics emerged in meeting military needs, and it has been developed based on this fundamental over the years. Planning is the critical factor of linking logistics chains. Therefore, it is not easy to achieve any retail, production, or marketing organization without logistical support.

It is known that the history of warehousing is almost as old as humanity. In the early stages of society, life was being maintained by hunting and gathering. After that, the storage problem of this gathered or hunted thing occurred. Therefore, people began to store the crops and animals in their 
way. For example, animals have not been killed because of meat spoilage quickly. And they have been kept by storing alive. That is why, in English, synonymous with the herd is named as "livestock." Thus, primitive warehousing has been started [2]. Then, products have begun to move from one place to another. And, this process brought along the storage needs till shipped or storage at transfer centers. With the industrial revolution, harbor warehouses had not sufficed. And the storage need has occurred for the production in ateliers that transformed to the factory.

In the early 1990s, packaging showed up to speed up loading, unloading, put-away, and picking processes, which take much time during storage. For example, in 1931, while a truck that loaded 13.000 boxes of canned food could be unloaded in 3 days, today is reduced to $4 \mathrm{~h}$ if we palletized the same product amount. As palletized production increased, vehicles and machines that allow palletized products to be easily handled within the warehouse began to emerge. Simultaneously, thanks to these machines and cars, height/floor concepts have occurred in the warehouse, and the warehouses have started to be used with maximum capacity. The last milestone of storage was the emergence of AS/RS warehouses [2].

From past to present, logistics processes have been analyzed as one of the most critical expense items for companies. Companies that cannot manage their logistics processes well cannot reach the desired growth rates, and some even disappear. Since logistics is a process with a lot of input and output, it is necessary to make accurate analyses to reach maximum efficiency. To this end, scientific studies have been conducted with different methods from past to present. The outputs were applied to the processes, and certain know-how was obtained. Besides, companies that do not have sufficient logistics know-how have applied to expert companies to manage their logistics processes. The concepts of 3PL and 4PL have emerged for this reason.

As mentioned above, logistics processes have a significant influence on organizations' efficiency, and logistics has a different kind of optimization/decision problems. In logistics system optimization, proper warehouse location selection is a significant problem [3]. One fundamental of the supply chain is warehouses, and it has a considerable effect on the success or failure of a business [4].

Warehouse location selection is an MCDM problem that should be evaluated according to some criteria. This criterion can be both qualitative and quantitative. And the best alternative is chosen by comparing this alternative using MCDM techniques. Such decisions are all critical to companies, because they are costly and difficult to fix and start over [4]. In the past years, hundreds of studies have been done related to the warehouse selection problem. This study, it is aimed to investigate a more specific topic of warehouse location selection. Therefore, this particular topic is warehouse location selection in cold chain logistics.

Tons of food spoil every year, since they have not been kept under correct temperature or humidity conditions. For example, every year, vegetables and fruits valued at almost 75 billion $¥$ are spoiled in China shipping. There are corresponding to 370 million tons of vegetables and fruits which are thrown can meet the needs of a town of 200 million populations [5]. Therefore, this is a huge number that should be considered. We need to achieve real-time monitoring of some important parameters to keep this product not to be spoilage in the warehouse operations or during delivery. New tech solutions and IT systems provide useful methods to monitor this parameter such as track and trace services, temperature, invoice, etc. [6].

This study's main scope is to give an alternative point of view for warehouse location selection in the Arabian Gulf region's cold chain logistics that consists of seven states. These are Qatar, Oman, Kuwait, Bahrain, Saudi Arabia, Iraq, and UAE. Since the annual average temperature is around $37^{\circ} \mathrm{C}$, cold chain warehousing and cold chain transportation have an essential role in providing a successful supply chain of perishable goods in this region. If we consider the very high temperature and humidity levels, cold chain logistics have become important more than ever to maintain optimum shelf life for perishable goods and products.

Section 1 explains the general scope of the study. Section 2 presents a detailed literature review about Supply Chain, Logistics, Warehouse Location Selection, Cold Chain Logistics, 3PL concept, and IVNF EDAS. Section 3 mentions critical criteria and sub-criteria, Alternatives have been determined and stated in the same section. Section 4 discusses the theoretical base of IVNF EDAS, which has been used in the project's computational study. Section 5 provides the details regarding how numerical example was performed and the study results. Section 6 contains the conclusion of the study. The final section recommends potential studies that can be done in the future.

\section{Literature Review}

\subsection{Warehouse Location Selection}

In today's world, most organizations avoid making strategic decisions that lose money/time and reduce their service level. Because they all try to make more profit/benefit with lower cost and time. Therefore, supply chain and logistics management play an essential role in it. It influences organizational performance in the context of quality, price, and flexibility [7].

Warehouse location selection is one of the most critical decision problems for organizations that need storage. 
Hundreds of research have been conducted by MCDM researchers over the years. The selection of an efficient warehouse is a difficult task as it involves qualitative and quantitative factors, and changes in the operating environment make the selection process a tedious one [3].

The initial phase of research on warehouse location selection focused mainly on cost reduction, and slowly, it got shifted to facilities of transportation, infrastructure, and labor [3].

Raut et al. performed [3] a study regarding warehouse selection of an Indian chemical product company that would like to aggressively expand its services through the Middle East and East Africa. It is impossible to take this high-level decision using the conventional method. Raut et al. have used [3] AHP with 11 criteria in their study:

1. Governmental policies and the regulations,

2. Climatic conditions of the region,

3. Technology availability,

4. Strategic location,

5. Availability of skilled workforce,

6. Safety measures availability,

7. A provision for storage and disposal of toxic substances,

8. Provisions for energy saving,

9. Other organizations using the facility,

10. Availability of parking facilities,

11. Provision for water management.

Warehouse location selection problems are not only valid for 3PL's or production companies. It is also an important strategic decision for charities. Oztaysi et al. have performed [8] a study on warehouse selection for charity foundations, because the warehouse location in humanitarian logistics has high importance, since it determines the disaster response's success after an event.

The conventional decision-making tools used for a warehouse location selection problem tend to be less efficient to overcome the verbal assessments' loose or uncertain nature. Oztaysi et al. have used [8] the Hesitant Fuzzy AHP model as the MCDM technique. They determined five main criteria:

1. Geographical location,

2. Transport connectivity,

3. Cost

4. Stable government,

5. Labor availability.

All criteria have a different kind of sub-criteria. For example, geographical location has four sub-criteria: proximity to disaster areas, logistics experts, availability, warehouse security, proximity to urban facilities, and closeness to other warehouses. Transport connectivity includes the sub-criteria airport and seaport availability, proximity to beneficiaries, sufficient warehouse infrastructure, adequate warehouse facility, and warehouse accessibility. Cost has five sub-criteria: storage cost, cost related to logistics, land cost, labor price, and replenishment cost. The stable government attribute has four sub-criteria cooperation with logistics agents, political and economic stability, existence of other agents (such as NGOs), and IT/Communication. Finally, the sub-attributes of labor availability are skilled and educated personnel, flexible customs regulations, population density, and climate [8].

Dey et al. tried [9] to bring a new perspective to warehouse/plant location selection. They have used the Group Decision-Making (GDM) method, which is defined as finding and reaching a shared decision according to consensus, political, or rational mechanism. The most critical parameter of the GDM method can be heterogeneity, because it has a significant impact on the realistic evaluation of criteria and alternatives. A pairwise comparison matrix is used to determine the importance of heterogenic degrees of expertise. Since this method may be biased, the consistency check control of AHP is used to cope with this. Dey et al. have handled [9] a case study for an Indian auto company. This company wishes to spread to other countries to gain a competitive advantage against its competitors in the automobile market. That is why, the company needs to decide its new plant's appropriate location. Four different selection criteria have been taken into consideration. These are availability of markets, transportation facility, space availability, and cost. First, criteria were ranked, then well-known MCDM methods are used to make the proper selection. The alternatives' ranking results regarding SAW, VIKOR, COPRAS, and PROMETHEE methods have found the same under homogeneous conditions. The top-ranking results of the alternatives for SAW, TOPSIS, VIKOR, and ELECTRE I methods remain the same under heterogenic conditions.

The most important feature of the subjective/qualitative criteria is that they are unproven, uncertain, and indefinite quintessentially. These criteria are mostly defined by a verbal factor measured by an individual's experience, sense, and perception. The availability of skilled and educated labor or proximity to both markets and customers can be counted as subjective/qualitative criteria in the warehouse location selection problem. As for objective/quantitative measures, these are exemplified with speed, cost, lifecycle, weight, etc., as it is clear that these criteria are quantitative and measurable [10].

As we can see above, subjectivity and objectivity are other important parameters that can affect the result of MCDM studies. Dey et al. have proposed [10] three fuzzy MCDM techniques to handle both objective and subjective criteria. The study's primary purpose was to select the best 
warehouse location option for a reputed South East Asian company. Six appropriate selection criteria were used to evaluate and choose the best warehouse location. These are availability of markets, transportation facility, land availability, political stability, proximity to customers, and cost. While the first five criteria are subjective, the last criterion (cost) is objective. As a result of this study, the same rankings were found using FTOPSIS, FSAW, and FMOORA methods.

Roh et al. have conducted [11] a study related to humanitarian relief logistics. And, they have tried to find crucial criteria for locating warehouses, which has been relatively ignored in humanitarian logistics compared to commercial logistics. Five main criteria have been used in this study: location, logistics, national stability, cost, and cooperation. These main criteria have some sub-criteria. Proximity to potential beneficiaries, geographical position or place, donor's opinion, location availability with no disaster, climate, proximity to other warehouse locations, and closeness to potential disaster areas have been evaluated within the location criterion. Political, social, and economic stability within National Stability. Labor, land, storage, replenishment, and logistics within cost. Host government, International NGO, Local NGO, UN, neighbor countries, and logistics agents within cooperation.

Dey et al. have published a paper that proposes an alternative warehouse selection approach to assist decision-makers [12]. In this paper, he has integrated three different MCDM techniques, and these are FST (fuzzy set theory), SAW (simple additive weighting), and FRS (factor rating system). Four criteria have been taken into account: transportation availability, skilled workforce, climatic conditions, and investment cost.

Warehouse location is generally one of the most critical and strategic decisions in optimizing logistic systems [4]. The procedure of making location decisions typically covered by the following four steps such as:

- Determination of criteria to be used for location alternative evaluations

- Determination of crucial criteria and essential factors, and criteria weighting

- Determination of alternative sites to be evaluated in terms of criteria

- Assessment of the possible alternatives and make the best selection.

Ashrafzadeh et al. have chosen 15 essential criteria in their study [4]. These are labor costs, transportation costs, handling costs, land cost, skilled labor, availability of labor force, land availability, climate, mode of transportation availability, reliability and quality of different modes of transportation, telecommunication system infrastructure, quality and reliability of utilities, closeness to customer, closeness to supplier, lead time, and responsiveness. Then, they have used the Fuzzy TOPSIS method to aggregate the ratings and generate an overall performance score for measuring each alternative.

Ozcan et al. have conducted a comparative analysis of the three most widely used primary methodologies [13]: AHP, TOPSIS, and ELECTRE. This study's criteria are movement flexibility, the average distance to shops, unit price, the average distance to leading suppliers, and stock holding capacity. AHP is a useful technique on criteria weights' calculation, and TOPSIS and ELECTRE are also helpful to rank alternatives. To make the paper aimed to give an optimization point of view, Grey Theory has been used. When TOPSIS and ELECTRE methods were used, similar results have been obtained.

Singh et al. have mentioned the vague nature of human decision-making and have tried to overcome this difficulty using Fuzzy AHP methodology, since conventional methods were not sufficient [14]. In their study, three main criteria have been used: infrastructure, government, and market. Infrastructure covers three sub-criteria: transport and connectivity, electricity and water supply, and IT communication setup. Government has three different sub-criteria named as cost of land, taxation policies, and incentives. The market criterion has three sub-criteria: market size, proximity to the primary market, and market growth scope.

Demirel et al. and Beg et al. have used Choquet integral to make the relatively best warehouse location selection and best bike purchasing $[15,16]$. Auephanwiriyahul et al. proposed [17] Choquet integral, in which measurable evidence is represented in terms of intervals, whereas fuzzy measures are real numbers, which is an extension of the standard Choquet integral. Demirel et al. have used [15] the following as their study's primary criteria: cost, labor characteristics, infrastructure, markets, and macro-environment.

They have also evaluated the following sub-criteria within under single main criteria. Cost main criterion consists of handling costs, labor costs, transportation costs, tax costs, and financial incentives. Labor characteristics consist of skilled and trained labor, and adequate labor force. Infrastructure main criterion consists of the mode of transportation availability, reliability, and quality of different modes of transportation. Market main criterion consists of distance to the supplier, distance to customer, responsiveness, and lead time. Macro-environment criterion consists of construction and zoning plan, industrial regulations, and government policies. The benefits of using Choquet integral are that it considers the relationship between criteria [15].

Kaboli et al. experienced an MCDM methodology for the correct and effective location selection problem [18]. Fuzzy AHP methodology has been used to evaluate criteria. These criteria are stated as climatic condition, work culture, 
housing facility, transportation availability, and recreational facility.

According to Chu, selecting a facility location is vital to industrial organizations to maximize resource utilization and minimize cost [19]. TOPSIS is one of the MCDM techniques based on alternatives evaluated by $\mathrm{n}$ criteria. This best alternative can be said as a single point somewhere over n-dimensional space. Geometric relationships can be established between m location points. The most optimum and ideal alternative has the best values in terms of all considered criteria, while the negative-ideal solution has the worst calculation values. TOPSIS methodology determines selection as a point or location which are closest to the optimum solution and farthest from the negative-ideal point at the same time [19]. Availability of skilled workers, power availability, transportation availability, investment cost, and community attitude has been defined as the study criteria.

Even if MCDM problems have a very ancient historical background, newer techniques to solve them would never stop emerging. Besides the warehouse selection problem's efforts, recent studies on new MCDM techniques are available. Riaz et al. have introduced soft multi-set topology to evaluate MCDM problems concerning real-life applications [20].

A recent assessment of the sustainability of rural tourism potential in the Brcko District of Bosnia and Herzegovina has been conducted using FUCOM, ARAS, and CRITIC methods [21]. For instance, in manufacturing studies, recent studies have been published to create an approach to MCDM problems using measurement alternatives and ranking according to compromise solution (MARCOS) [22].

While some of them have characteristics of methodology comparison, others aim to make the best decision for warehouse location selection using proven scientific methodologies, such as AHP, TOPSIS, PROMETHEE, MAUT, CBR, DEA, FST, SMART, GP, ELECTRE, and SAW [23]. As for this study, a new scientific method called IVNF EDAS has been used.

The EDAS method can recognize the conflicting attributes by computing the average solution based on two distance measures: PDA (Positive Distance from Average) and NDA (Negative Distance from Average). We evaluate options with higher PDA values and lower values of NDA as the best choices. Many scholars broadly studied MCDM methods such as VIKOR, ELECTRE, TOPSIS, PROMETHEE, GRA, MULTIMOORA, TODIM, etc. Compared to the existing methods, the EDAS model owns the credit of only taking average solutions into account concerning decision-makers' intangibility and the ambiguity of the decision-making environment to obtain more valid and useful aggregation results.

Since we always face the decision-maker subjectivity in MCDM uncertain environment. Decision-makers should have the same level of knowledge, background, and experience to avoid uncertainty, but they can always differ in skills, personality, or expertise.

In the EDAS method, the result obtained from the average solution eliminates the risk of the decision-maker's bias towards an option. The result being inferred from an average solution already normalizes the input, which narrows the optimum solution's deviation to a far great degree. It represents a more reliable and accurate solution than other MCDM techniques to real problems.

\subsection{Cold Chain Logistics}

\subsubsection{The Emergence of Cold Chain}

British fishers had first experienced temperature-sensitive goods in 1797. Natural ice has been used to keep hunted stock fresh while at sea for long fishing. Dairy products produced in rural areas have been sent to markets in urban areas in the late 1800s [24].

Cold storage also had an essential role in the intercolonial food and derivatives trade. For instance, in the late 1870s and early 1880 s, frozen mutton carcasses and meat have been shipped to France from South America. On the other hand, Great Britain has met their beef need by importing it in frozen form from Australia [25], and also, they have met the requirements of pork and derivatives from New Zealand. Thus, it was promoted to ship surpluses in developing countries to Europe, where a shortage of meat happened [24].

In 1902, United Food Company used temperature-controlled (reefer) ship for the first time. And the boat has been used for the banana trade. Thanks to this development, the world's top consumed and preferred fruit has been the banana.

The temperature-controlled movement of pharmaceuticals and medical products is a much more recent activity than the shipping of refrigerated or frozen food. Since the 1950s, logistical third-party companies began to find and implement new methods for successfully transporting these goods. Before these developments, cold chain processes were mostly managed in-house by the manufacturer's self [24].

It is quite clear that the management of the cold chain should be evaluated as a factor that directly impacts community health. Fungal, bacterial, and microbial shipment contamination can be reduced using refrigerated and cooled transportation equipment. Moreover, having a practical transport and distribution system for medicals such as vaccines will significantly impact solving urgent health problems [24].

Nowadays, temperature-sensitive product producers have become aware of the importance of temperature-controlled logistics. While some specialize in cold chain logistics by 
getting consultancy, some give this management to 3PL or 4PL companies that are already specialized in this area. Thus, organizations make their logistics management much more productive and reduce their spoilage-based costs. On the other hand, to prevent wasting food or other products is started to evaluate as social responsibility.

\subsubsection{Cold Chain Concept}

The importance of protecting temperature-sensitive goods is increasing day by day. Research shows that the movement of temperature-sensitive goods under the right conditions is crucial to keeping them fresh and long-lived. The fact that freshness in these products directly impacts human health makes the issue more critical. That is why, regulations and legislations are prepared by governments or standards such as GMP (Good Manufacturing Practices), GDP (Good Distribution Practice), and GWP (Global Warming Potential) are prepared by other authorized organizations to standardize the processes of this business. From production to consumption, while dry products can be managed using some simple standards and conditions, cold chain required more complex standards and requirements. The difference of cold chain from other logistics processes emerges right this point [26, 27].

Cold Chain includes all processes such as storage, transportation, etc. Professionals must apply these processes to maintain their properties at every stage, from the production of frozen/cold food to consumption. That is why, the receiving dock, shipment dock, preparation and loading area, and packaging area must be all maintained, so that the product retains its temperature [28]. Because, what happens if the cold chain breaks? Microorganisms start to reproduce rapidly in the product. It may even reach levels that threaten human health. A cold room can be defined as cooled spaces under suitable conditions and controlled humidity conditions and insulated against heat and moisture gain from the external atmosphere to store foodstuffs for more extended periods than they can be stored in normal conditions. A cold room's primary function is to provide constant temperature and relative humidity [29].

Cold warehouses are structures that can be constructed as reinforced concrete or prefabricated. Insulation standards make heat insulation and vapor diffusion of cold warehouses. In cold warehouses, moisture control is designed to be adjusted according to the type of foodstuff. The whole cooling system can be designed with fully automatic control and overload protection. Vehicles have platforms suitable for loading and unloading. There are cooling and freezing rooms that can be used independently. Fast-freezing (shocking) rooms are available through standards. The cold rooms have a homogeneous ambient temperature. Cold storages are designed with the infrastructure that can be cleaned quickly and easily. According to the official gazette, the temperature increasing tolerance cannot be more than $3{ }^{\circ} \mathrm{C}$. During storage, storage, and transport of fast-frozen foods, ambient temperature is recorded frequently and regularly using appropriate measuring and recording equipment. All are measuring and recording devices used for monitoring the temperature must comply with TS EN 12830, TS EN 13485, and TS EN 13486 standards. Food operators must have documents, showing that these devices comply with the relevant TSE standards. All these standards and conditions make the cold chain a specific warehousing method [30, 31].

The cold chain is a concept that provides temperature control in the supply chain, and it is pretty crucial for the management of both the food and pharmaceutical sectors [32]. The cold chain includes the transportation and distribution of temperature-sensitive goods throughout a supply chain via heat keeping and refrigerated warehousing, picking, packing, packaging, and distribution methods. Temperature-controlled cargo ships, railcars, trucks, air cargo, and refrigerated containers can be evaluated as cold chain transportation. This shipment methods allow the cold chain to be protected $[33,34]$.

Also, we need temperature-controlled warehouses for the proper storage of temperature-sensitive products. According to Rodrigue et al., the cold chain's main elements include the following [24]:

- Cooling systems

- Cold storage

- Cold transport

- Cold processing

- Cold distribution.

According to Singhal et al., the number of cold stores and total cold storage capacity has increased by nearly $50 \%$ and $60 \%$, respectively, between 2004 and 2014 [35].

Singh et al. have stated in their studies that almost $30 \%$ of vegetables and fruits go for nothing because of ineffective management of the cold chain in India [36]. In their research, managing the value chain of temperature-sensitive foodstuffs or pharmaceuticals has been defined as a cold chain [36]. The purpose of the study was to decide on the best 3PL company. Ten criteria have been determined to evaluate this study using Fuzzy TOPSIS and AHP methods together. These are warehousing and transportation cost, facilities of warehousing, facilities of infrastructure, customer service management and reliance, management of network facilities, capabilities for material handling processes, quality control and inspection check, process automation, innovations and effectiveness' of cold chain processes, application for track and trace, and process flexibility rate.

Failure to keep the food's temperature during the logistics process, or breakage of the cold chain, is a considerable risk 
for both the supplier and the buyer. It will reduce the products' economic value or make the products completely unusable. Loss of monetary value or making products ineffective is a substantial financial burden for producers [37]. Nutritious and healthy food demand is increasing daily in developing and developed countries. And also, it is announced that frozen product demand was reached US $\$ 224.74$ billion in 2018, and it hits US $\$ 293.75$ billion in 2019 [38].

Zhang et al. stated that the global world is faced with shortages of third-party logistics companies for temperaturesensitive products [39]. And this happened because of

- Low capacity and space use rate.

- Low yearly utilization rate because of season factor.

- Faced difficulties to provide and keep the product quality.

- Low efficiency because of manual works timeless updates.

The safety and quality of foods can be ensured by temperature control. There are three classification groups of foods. If a product or food temperature is below minus eighteen degrees Celsius, it is a frozen product or food. If the room temperature is best for a product or food, it is ambient. Finally, products are evaluated as chilled if they need to be kept between $0{ }^{\circ} \mathrm{C}$ and $15^{\circ} \mathrm{C}$ [40]. In Germany, cold storage is classified into four groups as below:

- Plant cold stores with 20 products and temperatures are below $-20^{\circ} \mathrm{C}$.

- Central cold stores with 80 products and temperature are below $-24{ }^{\circ} \mathrm{C}$.

- Distribution cold stores with 200 products and temperature are below $-20^{\circ} \mathrm{C}$.

- Freezing cabinets with 210 products and below $-18^{\circ} \mathrm{C}$.

Temperature conditions and rules have been determined differently by each country. This happened because of different measurement units of temperature, other feeding habits. And, this increases misinterpretations and complexity of coordination [38].

- The BFFF (British Frozen Food Federation) has classified frozen foods when the temperature ranges between $-20^{\circ} \mathrm{C}$ and $-28^{\circ} \mathrm{C}$, and it should have the temperature tolerance to reduce $3-18{ }^{\circ} \mathrm{C}$.

- According to ASHRAE (American Society of Heating, Refrigerating and Air-Conditioning Engineers), frozen products' temperature should be ranged between $-23{ }^{\circ} \mathrm{C}$ and $-29{ }^{\circ} \mathrm{C}$ for storage.

- The IFFI (Italian Frozen Food Institute) accepts $-22^{\circ} \mathrm{C}$ for frozen goods' storage [41].
- Temperature conditions' indicator shortly products can be evaluated in four groups as stated in Fig. 1 and their explanation [42];

- It is called "frozen" up to $-25^{\circ} \mathrm{C}$ and ice cream can be the best example, and continues to $-18{ }^{\circ} \mathrm{C}$ for the other products.

- Fresh poultry and meat and most dairy products, fruits, and vegetables are called "cold chill" from 0 to $1{ }^{\circ} \mathrm{C}$.

- The ideal temperature for cheeses, fats, or butter products is called "medium chill", which is $5{ }^{\circ} \mathrm{C}$.

- Bananas, exotic fruits, eggs, and potatoes are kept under unfamiliar chill conditions, which is $10-15^{\circ} \mathrm{C}$.

Stragas et al. have stated that some authorities and legislation about perishable goods exist [6]. The European Food and Safety Authority (EFSA) provides independent scientific advice and clear communication on existing and emerging risks. The U.S. Food and Drug Administration (FDA) is responsible for protecting public health by ensuring the safety and security of drugs, biological products, medical devices, USA food supply, cosmetics, and products that emit radiation. Regulations are Regulation (E.C.) No 178/2002: this regulation formulates principles to protect human health; Regulation (E.C.) No 1642/2003: this regulation is amending Regulation (E.C.) No 178/2002 additionally prerequisites that characterize food law; Regulation (E.C.) No 852/2004: this regulation emphasizes that food safety should be ensured starting from the production.

There has also been an agreement regarding transportation and handling, and warehousing of temperature-sensitive products in 1970. This agreement is signed to ensure that operating conditions meet the technical or biological standards listed [43]. Turkey is not a party to this agreement signed in Geneva [44].

The cold chain has different aspects as technology, process, and science. Interrelated operations need a process for effective cold chain management of perishable goods [24]. We use technology to monitor and measure conditions during storage and shipment. The cold chain also needs biology and chemistry to manage food perishability.

The cold chain has five fundamentals: cooling systems, cold storage, cold transportation, cold processing, and cold distribution.

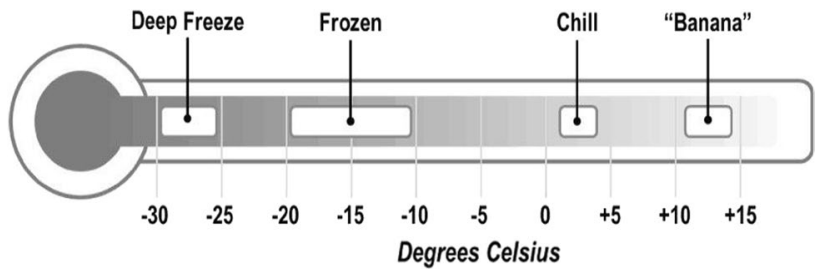

Fig. 1 Temperature condition classification 
- Cooling systems provides foods to be kept under the right temperature during the different process (e.g., storage, processing, or transportation).

- Cold storage provides facilities or warehouses for the correct storage of foods or goods.

- Cold transport is used to deliver temperature-controlled food or goods under the right humidity and temperature conditions. And also, it tries to protect the integrity of them.

- Cold processing provides necessary equipment and materials to ensure correct sanitary and health conditions.

- Cold distribution plays an important role in delivering the right product to the right place in the right temperature conditions.

The market has some issues and obstacle such as lack of know-how, lack of trained manpower, lack of backward and forward linkages, lack of trust concerning the viability of cold chain projects, high capital investments, high operational cost due to high cost of power, and problems of optimization in reefer transport $[45,46]$.

In this study, warehouses, which are one of the most important parts of cold chain logistics, have been handled. Because it is often not possible to sell a manufactured product immediately, that is why, we need to store our product under the right conditions. These conditions are much more sensitive, for perishable products, and you can find some examples of these conditions in Table 1.

Management of the cold chain should be evaluated as a factor that directly impacts community health. Refrigerated and cooled transportation equipment can reduce fungal, bacterial, and microbial shipment contamination using refrigerated and cooled transportation equipment. Temperaturesensitive warehouse location selection is a multi-criteria decision-making problem. Different types of criteria have been used from past to present according to the purpose of the study.

\subsubsection{Storage Conditions}

We can evaluate warehouse location selection problems based on fuzzy logic, because the criteria are not absolute.
However, they can be near the absolute must. As for temperature-controlled warehouse location selection, the fuzzy logic approach is not preferred, because this problem has much more strict and absolute must-criteria such as government regulations, IT infrastructure for instant visualization, and quality WM system that allows well FEFO or FIFO tracking. That is why, a new scientific method named interval-valued neutrosophic EDAS has been used in this project to give a new scientific point of view for warehouse selection in cold chain logistics.

\subsection{Third-Party Logistics Concept}

Logistics is a specific field of expertise, and it has plenty of parameters that you need to take into account to optimize your processes and reduce logistics costs. Effective logistics management is crucial for producers, suppliers, distributors, or vendors. Companies with inefficient logistics management experience loss of sales, loss of prestige, loss of money, and loss of labor. Companies that do not want to experience such problems get external support from companies with in-depth knowledge and know-how about warehousing and transportation. We call these companies 3PL or 4PL suppliers.

3PL supplier is an independent firm that manages logistics processes on behalf of the customer under a contract [47]. 3PL suppliers support companies to achieve operational efficiency, greater flexibility, improved customer service, and better focus on their own business [48].

The areas which 3PL suppliers support can be as below

- Logistics center investment

- Warehouse layout

- Warehousing activities

- Transportation activities

- Value Added activities

- Material handling devices

- Warehouse management system

- Transport management system

- Skilled labor.

Table 1 Storage conditions

\begin{tabular}{lllll}
\hline Food & Optimum & $+10{ }^{\circ} \mathrm{C}$ & $+20{ }^{\circ} \mathrm{C}$ & $+30{ }^{\circ} \mathrm{C}$ \\
\hline Fresh fish & 10 days at $0{ }^{\circ} \mathrm{C}$ & $4-5$ days at $10{ }^{\circ} \mathrm{C}$ & $1-2$ days at $20{ }^{\circ} \mathrm{C}$ & Few hours at $30{ }^{\circ} \mathrm{C}$ \\
Milk & 2 weeks at $0{ }^{\circ} \mathrm{C}$ & 7 days at $10{ }^{\circ} \mathrm{C}$ & $2-3$ days at $20{ }^{\circ} \mathrm{C}$ & Few hours at $30{ }^{\circ} \mathrm{C}$ \\
Vegetable & 1 month at $0{ }^{\circ} \mathrm{C}$ & 2 weeks at $10{ }^{\circ} \mathrm{C}$ & 1 week at $20{ }^{\circ} \mathrm{C}$ & $<=2$ days at $30{ }^{\circ} \mathrm{C}$ \\
Potato & $5-10$ months at $4-12{ }^{\circ} \mathrm{C}$ & 2 months at $10{ }^{\circ} \mathrm{C}$ & 1 month at $32{ }^{\circ} \mathrm{C}$ & $<=2$ weeks at $42{ }^{\circ} \mathrm{C}$ \\
Mango & $2-3$ weeks at $13{ }^{\circ} \mathrm{C}$ & 1 week at $23{ }^{\circ} \mathrm{C}$ & 4 days at $33{ }^{\circ} \mathrm{C}$ & 2 days at $43{ }^{\circ} \mathrm{C}$ \\
Apple & $3-6$ months at $-1{ }^{\circ} \mathrm{C}$ & 2 months at $10^{\circ} \mathrm{C}$ & 1 month at $20{ }^{\circ} \mathrm{C}$ & Few weeks at $30{ }^{\circ} \mathrm{C}$ \\
\hline
\end{tabular}




\subsection{Interval-Valued Neutrosophic Fuzzy EDAS}

Companies and organizations face a different kind of decision-making problem in their daily routine. Sometimes, this can be a small matter that can be evaluated quickly with a traditional and unscientific method; sometimes, it can be a much more complex and risky decision. And, if you are talking about the decision of something, there should be different alternatives with different attributes, and traditional methods cannot solve this problem. It would help if you made some scientific calculations to analyze the best option.

Elements are inside or outside of the set in general set theory [49]. A solution can be infeasible or feasible in the optimization and the logic of Boolean. However, in life facts, all the things are not confident and have a degree of it, and this cannot be explained with conventional logic. Therefore, below improvements have been done to cope with this uncertainty

- Fuzzy sets theory has been introduced [50] in 1965.

- Zadeh et al. developed type-n fuzzy sets to handle membership function uncertainty [51].

- IVFSs has been used by Jahn, Zadeh, Sambuc, and Grat$\tan$ Guiness for the first time in 1975.

- IFSs have been introduced by Atanassov. This method determines the membership function with a degree of non-membership and membership by considering decision-makers' hesitations [52].

- Hesitant fuzzy sets started to be studied [53]. These sets accept the sets that have only one element. There is no difference with standard fuzzy theory. The only difference is the sets with a single element.

- Neutrosophic sets, which is another intuitionistic fuzzy sets, have been developed [54] to allow decision-makers to reflect their feelings for membership function definition.

- Neutrosophic fuzzy sets are becoming more useful in the MCDM area. A recent study has introduced an MCDM method based on single-valued neutrosophic graphs, accompanied by an illustrative example and a conducted comparative analysis to confirm the proposed method's feasibility and efficiency [55].

- Moreover, new hybrid aggregation techniques are used to evaluate an agricultural land selection problem to manage the ambiguity in single-valued neutrosophic information [56].

- Relatively new method named EDAS started to be widely used [57]. This method has some calculations according to the distance to the average solution [58].
IVNFSs can represent imprecise, uncertain, inconsistent, and incomplete information [59]. The neutrosophic sets consider the uncertainty of one set's members. Uncertainty relies on falsity, indeterminacy, or truth, and these are related to absoluteness or belongingness. Thanks to these calculations and observations, neutrosophic sets

- reduce the system's uncertainty factor.

- reduce indecision of incoherent information [60].

Shortly, all member of a set has a degree of truth, fault, and uncertainty. This degree can take any value between 0 and 1 [61].

Other MCDM techniques such as VIKOR and TOPSIS calculate the optimal solution based on min; distance from positive or best ideal solution simultaneously with a maximum distance from the negative solution. However, the best alternative in the EDAS method is calculated based on the distance value from AV (average solution) [58]. EDAS method calculations are done by comparing average solutions and alternatives. The average solution's distance is calculated for every single alternative according to all possible criteria [60]. It aims to determine the best solution by making two different distance calculations called the NDA (negative distance calculation from AV) and the PDA (positive distance calculation from AV). To reach the best alternative, we need to find the alternative with a lower NDA and a larger PDA.

Neutrosophic sets are used to extend the EDAS method for the first time. The hybrid use of neutrosophic sets considers the opinions and tendencies of decision-makers [62]. Therefore, we can observe truthiness $(\mathrm{T})$, falsity $(\mathrm{F})$, and indeterminacy (I) of decision-makers. Thus, such advantages as absoluteness, reflection caused by decision-makers' relativity, and subsets' independence, which provide colossal freedom to determine subsets' values, are used and utilized.

Fuzzy sets cannot always deal with ambiguities in different MCDM problems. Some uncertainties, such as doubtful or vague inputs, are not managed. A decision-maker may say that the possibility that a statement is true or false would be 0.4 and 0.6 , respectively. The degree will be 0.3 if he or she is not certain. Fuzzy sets cannot deal with this issue. Neutrosophic fuzzy sets have been introduced with a degree of truth, indeterminacy, and falsity, respectively, which lies in a non-standard unit interval. The degree of truth, falsity, and indeterminacy of a specific statement cannot be specified accurately in actual circumstances but expressed by several possible interval values. The warehouse location selection problem needs such an interval-based approach to overcome 
the subjectivity of decision-makers who have various views, opinions, and experiences.

\section{Criteria and Sub-criteria}

There are lots of research on warehouse location selection topics, and if we are working on a selection of something, MCDM techniques come into play. If we would like to use these techniques in our research, we need to have some criteria. Without deciding on the right criteria, we cannot get the correct result using these techniques, because almost all of them wait for proper criteria selection for calculation and evaluation.

In this study, third-party logistics companies are handled according to their capability to manage warehouses for temperature-sensitive products. As we have mentioned before, 3PL companies provide successful logistics management to their customer. And they should run different customers in one location. That is why, the warehouse's location plays a crucial role in getting high customer satisfaction. If any organization wants to decide the best temperature-controlled warehouse location, it needs to evaluate the main criteria such as location, cost, warehouse facilities, macro-environment, and cooling facilities. You can find their sub-criteria below:

The first main criterion is "location", and it is related to the accessibility of the warehouse from some target and source points. The better the site, the more competitiveness. Right location selection takes you one step ahead of your competitors. Location's sub-criteria are proximity to potential markets, proximity to producers, proximity to seaports, main roads and airports, proximity to forwarding agents, climate conditions, and skilled workforce availability.

Proximity to potential markets: It is preferred to locate your site around market places, because it provides an advantage in reducing delivery times.

Proximity to producers: If you locate your site around producers, it will be much easier to reach new possible customers.

Proximity to a seaport, main road, and airport: It is preferred to quickly reach different transportation modes to plan your delivery in the most efficient way.

Proximity to forwarding agents: If you locate your warehouse near the forwarding agents, this will give you the advantage to find transportation at the right time, in the right way.

Climate conditions: It is not preferred to have a warehouse in places where climatic conditions negatively affect transportation.
Availability to the skilled workforce: Human resources is one of the essential parts of an organization. Enabling a skilled workforce will make your operation much more efficient.

The second is "cost" criteria, and it directly connects with the profitability of an organization. The lower the cost, the more the profit or, the more customer satisfaction. Overall financial burden includes the following as sub-criteria; storage cost, investment cost, rental cost, labor cost, transportation cost, and energy cost.

Storage cost: It means unit storage cost in terms of $\mathrm{m}^{2}$. It differs from location to location.

Investment cost: All investment projects have particular cost items, and investment cost is determined according to these items.

Rental cost: This cost also differs from one location to another according to the warehouse facilities.

Labor cost: Human resource is one of the project's cost items. That is why, it is preferred to choose a suitable location to reach a skilled workforce with minimum cost.

Transportation cost: If any site is far from main roads and main transportation modes, it will be added to your cost items.

Energy cost: It makes companies much more efficient in choosing a warehouse with a different type of energy solutions.

The third is related to "facilities" and opportunities provided by the warehouse. If you are a third-party logistics supplier, you need to have facilities and opportunities in your warehouse to get more customers. These facilities or features make customer's operations much better and increase your preferability. These can be structural suitability, parking facilities, hygiene facilities, hydraulic ramp facilities, adequate truck maneuver fields, security, stock holding capacity, separated waste field, and fair IT/network system.

Structural suitability: this is important, because you can use a storage area much more effectively than a poorly structured warehouse.

Parking facilities: As the company serves as a supplier, most customers, customers' guests, and possible customers will come to visit. And also you need a free field to park operation cars.

Hygiene facilities: This is also another critical criterion, because most of the product that will be stored will be food.

Hydraulic ramp facility: This criterion is vital, because it gives you flexibility during loading and unloading.

Adequate truck maneuver field: It is preferred to have a warehouse that is also friendly for trucks.

Security: Having a good security facility will increase customer trust. 
Stock holding capacity: Storage earnings are directly connected to this criterion. Because the more area, the more profit.

Separated waste field: To have a separated waste area is another reason to choose in our daily lives.

Adequate IT/network System: This is an essential criterion, because you cannot manage any operation with a low IT structure.

The fourth criterion is the "macro environment", consisting of government policies and industry regulations, and laws as sub-criteria.

Government policies: These affect warehouse investment decisions.

Industrial regulations and laws: It is impossible to use any warehouse that does not match requirements.

The last criteria are related to temperature, and it is named "cooling facilities". Having various suitable areas for dry, cold, or frozen storage makes you much more competitive and increases your preferability. You can serve other types of customers and different product ranges. Cold storage facilities, processing, and cold transportation are essential for the efficient cold chain management.

Cold storage: The sub-criterion must store perishable goods in the right conditions.

Cold processing: Temperature standards also should be provided during the handling process. That is why, we need this sub-criterion.

Cold transportation: This sub-criterion must also transport perishable goods to related destinations.

Location alternatives stated in Table 2 are evaluated based on criteria indicated in Appendix 1. These cities and countries are determined as Abu Dhabi (UAE), Dubai (UAE), Al-Ayn (UAE), Doha (Qatar), Manama (Bahrain), Riyadh (Saudi Arabia), Medina (Saudi Arabia), Jeddah (Saudi Arabia), Mecca (Saudi Arabia), Kuwait City (Kuwait), and Masqat (Oman). Arabian Gulf has been used as a sample region, because the annual average temperature is around $37^{\circ} \mathrm{C}$ in this region. Cold chain logistics has an increasingly important role when considering the region's very high temperature and humidity levels.

Table 2 Location alternatives

\begin{tabular}{llllll}
\hline$\#$ & City & Country & $\#$ & City & Country \\
\hline $\mathrm{A}_{1}$ & Abu Dhabi & UAE & $\mathrm{A}_{7}$ & Medina & Saudi Arabia \\
$\mathrm{A}_{2}$ & Dubai & UAE & $\mathrm{A}_{8}$ & Jeddah & Saudi Arabia \\
$\mathrm{A}_{3}$ & Al-Ayn & UAE & $\mathrm{A}_{9}$ & Mecca & Saudi Arabia \\
$\mathrm{A}_{4}$ & Doha & Qatar & $\mathrm{A}_{10}$ & Kuwait City & Kuwait \\
$\mathrm{A}_{5}$ & Manama & Bahrain & $\mathrm{A}_{11}$ & Masqat & Oman \\
$\mathrm{A}_{6}$ & Riyadh & Saudi Arabia & & & \\
\hline
\end{tabular}

\section{Methodology}

\subsection{EDAS Method}

The steps of the basic EDAS algorithm are stated as below.

Step 1: Most proper attributes are chosen, which can be used to describe the alternatives of a specific decision problem.

Step 2: Decision matrix is constructed according to Eq. 1. Performance rating of $i$ th alternative $\mathrm{A}_{1}, \mathrm{~A}_{2}, \ldots$ $\mathrm{A}_{\mathrm{n}},(j=1,2, \ldots, n)$ is $\mathrm{x}_{i j}$ with respect to $j$ th criterion $\mathrm{C}_{j}$ $(j=1,2, \ldots, m)$

$X=\left[x_{i j}\right]_{n \times m}=\left[\begin{array}{cccc}x_{11} & x_{12} & \ldots & x_{1 m} \\ x_{21} & x_{22} & \ldots & x_{2 m} \\ \vdots & \vdots & \ddots & \vdots \\ x_{n 1} & x_{n 2} & \ldots & x_{n m}\end{array}\right]$;

$W=\left[w_{1}, w_{2}, \ldots, w_{m}\right]$ for $i=1,2, \ldots, n$ and $j=1,2, \ldots, m$ where $w_{j}$ is weight of criterion $j$.

Step 3: Determine the average solutions with respect to all criteria as given in Eq. 2

$A V_{j}=\frac{\sum_{i=1}^{n} x_{i j}}{n}$.

Step 4: Calculate the PDA and the NDA matrices as given in Eqs. 3 and 4

$P D A_{i j}=\frac{\max \left[0,\left(x_{i j}-A V_{j}\right)\right]}{A V_{j}}$

$N D A_{i j}=\frac{\max \left[0,\left(A V_{j}-x_{i j}\right)\right]}{A V_{j}} ;$

$P D A_{i j}$ and $N D A_{i j}$ represent the positive and negative distances of $i$ th alternative from average solution in terms of $j$ th criterion, respectively.

Step 5: Obtain weighted summation of the positive and negative distances from average matrix

$S P_{i}=\sum_{j=1}^{m} w_{j} P D A_{i j}$

$S N_{i}=\sum_{j=1}^{m} w_{j} N D A_{i j}$

Step 6: Identify the normalized values of $S P_{i}$ and $S N_{i}$ for all alternatives, as given in Eqs. 7 and 8

$N S P_{i}=\frac{S P_{i}}{\max _{i}\left(S P_{i}\right)}$ 
$N S N_{i}=1-\frac{S N_{i}}{\max _{i}\left(S N_{i}\right)}$.

Step 7: Detect the appraisal score (AS) for all alternatives, as given in Eq. 9

$A S_{i}=\frac{1}{2}\left(N S P_{i}+N S N_{i}\right)$,

where $0 \leq A S_{i} \leq 1$.

Step 8: Rank the alternatives according to the decreasing values of appraisal score $A S_{i}$. The alternative with the highest $A S_{i}$ is the best choice among the others (Fig. 2).

\subsection{Interval-Valued Neutrosophic Fuzzy (IVNF) EDAS}

In this section, we propose interval-valued neutrosophic EDAS with all its details. Deneutrosophication technique for the interval-valued neutrosophic sets is enhanced and subtraction operation for the IVN sets is developed [63-66].

Definition 1: Let $x_{j}=\left\langle\left[T_{j}^{L}, T_{j}^{U}\right],\left[I_{j}^{L}, I_{j}^{U}\right],\left[F_{j}^{L}, F_{j}^{U}\right]\right\rangle$ be a collection of interval-valued neutrosophic number (IVNN) where $j$ represents decision maker $(j=1,2, \ldots, n)$. Based on the weighted aggregation operators of IVNNs, the IVN weighted arithmetic average operator (INWAA) is as in Eq. 10

$\operatorname{INWAA}\left(x_{1}, x_{2}, \ldots, x_{n}\right)=\sum_{k=1}^{n} y_{k} x_{j}$

where

$\left\langle\left[1-\prod_{k=1}^{n}\left(1-T_{j}^{L}\right)^{y_{k}}, 1-\prod_{k=1}^{n}\left(1-T_{j}^{U}\right)^{y_{k}}\right]\right.$,

$\left.\left[\prod_{k=1}^{n}\left(I_{j}^{L}\right)^{y_{k}}, \prod_{k=1}^{n}\left(I_{j}^{U}\right)^{y_{k}}\right],\left[\prod_{k=1}^{n}\left(F_{j}^{L}\right)^{y_{k}}, \prod_{k=1}^{n}\left(F_{j}^{U}\right)^{y_{k}}\right]\right\rangle$

and $y_{k}$ is the weight vector of decision-maker.

Definition 2: The ranking function of an IVNN which is given above is calculated as in Eq. 12
Step 1: Construct an IVN decision matrix for experts.

\section{Step 2: Construct aggregated IVN} decision matrix.

Step 3: Construct the average solution matrix of criteria weights regarding experts.

Step 4: Construct the matrix of average criteria weights.

Step 5: Calculate PDA and NDA.

Step 6: Weighted sum of PDA and NDA.

Step 7: Normalization of the $\mathrm{np}_{\mathrm{n}}$ and $\mathrm{sp}_{\mathrm{n}}$ values.

Step 8: Appraisal score calculation.

\section{Step 9: Ranking Alternatives.}

Fig. 2 Framework of the EDAS method

$\kappa(x)=\frac{\left(T_{x}^{L}\left(2-I_{x}^{L}-I_{x}^{U}\right)\right)+\left(T_{x}^{U}\left(2-I_{x}^{L}-I_{x}^{U}\right)\right)+\left(1-F_{x}^{L}\right)\left(2-I_{x}^{L}-I_{x}^{U}\right)+\left(1-F_{x}^{U}\right)\left(2-I_{x}^{L}-I_{x}^{U}\right)}{8}$,

where $x_{j}=\left\langle\left[T_{j}^{L}, T_{j}^{U}\right],\left[I_{j}^{L}, I_{j}^{U}\right],\left[F_{j}^{L}, F_{j}^{U}\right]\right\rangle$

Definition 3: A function is defined to find the maximum value between IVN set and zero as in Eq. 13:

$Z\left(x_{j}\right)=\left\{\begin{array}{l}x_{j}, \text { if } \kappa\left(x_{j}\right)>0 \\ 0, \text { if } \kappa\left(x_{j}\right) \leq 0\end{array}\right.$ where $x_{j}=\left\langle\left[T_{j}^{L}, T_{j}^{U}\right],\left[I_{j}^{L}, I_{j}^{U}\right],\left[F_{j}^{L}, F_{j}^{U}\right]\right\rangle$ and $0=\langle[0,0],[1,1],[1,1]\rangle$.

Definition 4: Let $X$ be a universe of discourse. An IVN set $N \in X$ is independently characterized by a truth membership function $T_{N}(x)$, an indeterminacy membership function $I_{N}(x)$, and a falsity membership function $F_{N}(x)$ for each $x \in X$, where $T_{N}(x)=\left[T_{N(x)}^{L}, T_{N(x)}^{U} \subseteq[0,1]\right], I_{N}(x)=\left[I_{N(x)}^{L}, I_{N(x)}^{U} \subseteq[0,1]\right]$ and $F_{N}(x)=\left[F_{N(x)}^{L}, F_{N(x)}^{U} \subseteq[0,1]\right]$. Then, they need to satisfy the 
condition of $0 \leq T_{N(x)}^{L}+I_{N(x)}^{L}+F_{N(x)}^{L} \leq 3$. Thus, the IVNS can be denoted as in Eq. 14

$N=\left\{\left\langle x,\left[T_{N(x)}^{L}, T_{N(x)}^{U}\right],\left[I_{N(x)}^{L}, I_{N(x)}^{U}\right],\left[F_{N(x)}^{L}, F_{N(x)}^{U}\right]\right\rangle \mid x \in X\right\}$.

We will denote Eq. 14 as $\left[T_{N}^{L}, T_{N}^{U}\right],\left[I_{N}^{L}, I_{N}^{U}\right],\left[F_{N}^{L}, F_{N}^{U}\right]$ for short. Let $a=\left[T_{a}^{L}, T_{a}^{U}\right],\left[I_{a}^{L}, I_{a}^{U}\right],\left[F_{a}^{L}, F_{a}^{U}\right]$ and $b=\left[T_{b}^{L}, T_{b}^{U}\right],\left[I_{b}^{L}, I_{b}^{U}\right],\left[F_{b}^{L}, F_{b}^{U}\right]$ be two INNs; the relations of them are shown as below

$$
\begin{aligned}
& a^{c}=\left\langle\left[T_{a}^{L}, T_{a}^{U}\right],\left[1-I_{a}^{L}, 1-I_{a}^{U}\right],\left[F_{a}^{L}, F_{a}^{U}\right]\right. \\
& a \subseteq b \text { if and only if } T_{a}^{L} \leq T_{b}^{L}, T_{a}^{U} \leq T_{b}^{U} ; I_{a}^{L} \geq I_{b}^{L}, I_{a}^{U} \\
& \geq I_{b}^{U} ; F_{a}^{L} \geq F_{b}^{L}, F_{a}^{U} \geq F_{b}^{U} \\
& a=b \text { if and only if } a \subseteq b \text { and } b \subseteq a \\
& a \oplus b=\left\langle\left[T_{a}^{L}+T_{b}^{L}-T_{a}^{L} T_{b}^{L}, T_{a}^{U}+T_{b}^{U}-T_{a}^{U} T_{b}^{U}\right],\left[I_{a}^{L} I_{b}^{L}, I_{a}^{U} I_{b}^{U}\right],\right. \\
& \left.\left[F_{a}^{L} F_{b}^{L}, F_{a}^{U} F_{b}^{U}\right]\right\rangle \\
& a \otimes b=\left\langle\left[T_{a}^{L} T_{b}^{L}, T_{a}^{U} T_{b}^{U}\right],\left[I_{a}^{L}+I_{b}^{L}-I_{a}^{L} I_{b}^{L}, I_{a}^{U}+I_{b}^{U}-I_{a}^{U} I_{b}^{U}\right],\right. \\
& \left.\left[F_{a}^{L}+F_{b}^{L}-F_{a}^{L} F_{b}^{L}, F_{a}^{U}+F_{b}^{U}-F_{a}^{U} F_{b}^{U}\right]\right\rangle .
\end{aligned}
$$

Definition 5: Subtraction operation of two IVN sets is given as follows:

$x \ominus y=\left\langle\left[T_{x}^{L}-T_{y}^{L}, T_{x}^{U}-T_{y}^{U}\right],\left[\max \left(I_{x}^{L}, I_{y}^{L}\right)\right.\right.$,

$\left.\left.\max \left(I_{x}^{U}, I_{y}^{U}\right)\right],\left[F_{x}^{L}-F_{y}^{L}, F_{x}^{U}-F_{y}^{U}\right]\right\rangle$

wh e r e $\quad x=\left\langle\left[T_{x}^{L}, T_{x}^{U}\right],\left[I_{x}^{L}, I_{x}^{U}\right],\left[F_{x}^{L}, F_{x}^{U}\right]\right\rangle$

a n d

$x=\left\langle\left[T_{y}^{L}, T_{y}^{U}\right],\left[I_{y}^{L}, I_{y}^{U}\right],\left[F_{y}^{L}, F_{y}^{U}\right]\right\rangle$.

Definition 6: Let $A=\left\langle\left[T^{L}, T^{U}\right],\left[I^{L}, I^{U}\right],\left[F^{L}, F^{U}\right]\right\rangle$ be an IVNN. The deneutrosophicated $A$ value $\kappa(x)$ is given by Eq. 16

$$
\begin{aligned}
\kappa(A)= & \frac{T^{L}+T^{U}+2-F^{L}-F^{U}+T^{L} \times T^{U}+\sqrt{\left(1-F^{L}\right)\left(1-F^{U}\right)}}{6} \\
& \times\left(1-\frac{I^{L}+I^{U}}{2}-\sqrt{I^{L} I^{U}}\right) .
\end{aligned}
$$

We use IVN sets in EDAS method to surpass incompleteness, indeterminacy, and inconsistency information in the system. The steps of the extended method are:

Step 1: Construct the IVN decision matrix $D_{j}$ with regard to $j$ experts, where the benefit and cost variables are $b_{m n}$ and $c_{m n}$, respectively. The columns are the alternatives (n) and the rows are the criteria $(\mathrm{m})$. The scale used to construct IVN decision matrix is given in Table 3 .

Here, we use $x_{j_{m n}}=\left\langle\left[T_{x}^{L}, T_{x}^{U}\right],\left[I_{x}^{L}, I_{x}^{U}\right],\left[F_{x}^{L}, F_{x}^{U}\right]\right\rangle$ notation to express IVNN with respect to expert $j$.

Step 2: Aggregate the decision matrix for obtaining average IVN decision matrix.
Table 3 Linguistic terms and their corresponding values

\begin{tabular}{lll}
\hline Scale & & Value \\
\hline CL & IVN & $\langle[0.15,0.25],[0.15,0.25],[0.85,0.95]\rangle$ \\
CLI & Weight & $\langle[0.08,0.24],[0.69,0.80],[0.85,1.00]\rangle$ \\
VL & IVN & $\langle[0.25,0.35],[0.35,0.45],[0.75,0.85]\rangle$ \\
VLI & Weight & $\langle[0.24,0.35],[0.58,0.69],[0.4,0.85]\rangle$ \\
L & IVN & $\langle[0.35,0.45],[0.45,0.55],[0.65,0.75]\rangle$ \\
LI & Weight & $\langle[0.35,0.46],[0.46,0.58],[0.63,0.74]\rangle$ \\
BA & IVN & $\langle[0.45,0.55],[0.55,0.65],[0.55,0.65]\rangle$ \\
BAI & Weight & $\langle[0.46,0.58],[0.35,0.46],[0.52,0.63]\rangle$ \\
A & IVN & $\langle[0.55,0.60],[0.65,0.75],[0.45,0.55]\rangle$ \\
AI & Weight & $\langle[0.52,0.58],[0.13,0.24],[0.46,0.52]\rangle$ \\
AA & IVN & $\langle[0.55,0.65],[0.55,0.65],[0.45,0.55]\rangle$ \\
AAI & Weight & $\langle[0.52,0.63],[0.35,0.46],[0.46,0.58]\rangle$ \\
H & IVN & $\langle[0.65,0.75],[0.45,0.55],[0.35,0.45]\rangle$ \\
HI & Weight & $\langle[0.63,0.74],[0.46,0.58],[0.35,0.46]\rangle$ \\
VH & IVN & $\langle[0.75,0.85],[0.25,0.35],[0.25,0.35]\rangle$ \\
VHI & Weight & $\langle[0.74,0.85],[0.58,0.69],[0.24,0.35]\rangle$ \\
CH & IVN & $\langle[0.85,0.95],[0.15,0.25],[0.15,0.25]\rangle$ \\
CHI & Weight & $\langle[0.85,1.00],[0.69,0.80],[0.08,0.24]\rangle$ \\
\hline
\end{tabular}

Step 3: Construct the average solution matrix of criteria weights with regards to experts. The weights are

$W=\left[w_{j}\right]_{1 m}$,

where $w_{j}$ is obtained using Eq. 1.

Step 4: Construct the matrix of average criteria weights. $A V_{n}=\left\langle\left[T_{A V}^{L}, T_{A V}^{U}\right],\left[I_{A V}^{L}, I_{A V}^{U}\right],\left[F_{A V}^{L}, F_{A V}^{U}\right]\right\rangle$ where the average weights of criteria with respect to scores are taken from the decision matrix.

Step 5: Calculate PDA and NDA according to benefit and cost criteria, respectively. As we mentioned above, benefit and cost variables are shown as $b_{m n}$ and $c_{m n}$

$P D A=\left[p d a_{m n}\right]_{m \times n}$

$N D A=\left[n d a_{m n}\right]_{m \times n}$,

where $\mathrm{PDA}_{\mathrm{mxn}}$ and $\mathrm{NDA}_{\mathrm{mxn}}$ denote the positive and negative distance performance value of the $\mathrm{n}^{\text {th }}$ alternative from average solution in terms of $m^{\text {th }}$ criterion, respectively

$p d a_{m n}=\left\{\begin{array}{l}\frac{Z\left(x_{m n} \ominus A V_{n}\right)}{\kappa\left(a v_{n}\right)}, \text { if } m \in B \\ \frac{Z\left(A V_{n} \ominus x_{m n}\right)}{\kappa\left(a v_{n}\right)}, \text { if } m \in C\end{array}\right.$ 
$n d a_{m n}=\left\{\begin{array}{l}\frac{Z\left(A V_{n} \ominus x_{m n}\right)}{\kappa\left(a v_{n}\right)}, \text { if } m \in B \\ \frac{Z\left(x_{m n} \ominus A V_{n}\right)}{\kappa\left(a v_{n}\right)}, \text { if } m \in C\end{array}\right.$.

Step 6: Calculate the weighted sum of PDA and NDA for all alternatives as in Eqs. 22 and 23

$s p_{n}=\sum_{n=1}^{l}\left(w_{j} \otimes p d a_{m n}\right)$

$n p_{n}=\sum_{n=1}^{l}\left(w_{j} \otimes n d a_{m n}\right)$

Step 7: Normalize the $s p_{n}$ and $n p_{n}$ values. The normalize values of $s p_{n}$ and $n p_{n}$ for all alternatives are calculated using Eqs. 24 and 25

$n s p_{n}=\frac{s p_{n}}{\max \left(\kappa\left(s p_{n}\right)\right)}$

$n s n_{n}=1-\frac{s n_{n}}{\max \left(\kappa\left(s n_{n}\right)\right)}$.

Step 8: Calculate the appraisal score $\left(a s_{n}\right)$ for all alternatives as in Eq. 26

$a s_{n}=\frac{1}{2}\left(n s p_{n} \oplus n s n_{n}\right)$.

Step 9: Rank the alternatives according to the decreasing values of appraisal score $\left(a s_{n}\right)$.

\section{Numerical Application}

As stated in previous sections, warehouse location selection for cold chain logistics has been experienced using neutrosophic EDAS, one of the MCDM techniques [63]. Arabian Gulf Countries are the target region of this selection problem, because the temperature, consumption, and importation indicators are pretty high. This study evaluates and selects the best candidate cities among the alternatives based on evaluation criteria and sub-criteria.

Since this is a decision-making problem, it includes decision-makers. This study's decision-makers are from three departments of one of the globally leading logistics companies. Related departments are Business Development Department, Operational Excellence Department, and Contract Logistics Department.

The business development department consists of sales and solution design experts. Sales team members work a lot to get a lucrative customer in terms of money and prestige.
Table 4 Scale for weighting the criteria

\begin{tabular}{lll}
\hline Expert & Explanation & Weights \\
\hline $\mathrm{DM}_{1}$ & Business development department & 0.40 \\
$\mathrm{DM}_{2}$ & Operational excellence department & 0.30 \\
$\mathrm{DM}_{3}$ & Contract logistics department & 0.30 \\
\hline
\end{tabular}

They prepare an offer for the tender according to company rules and the expected rate of return. They need the collaboration of different disciplines by doing this; these disciplines are operational excellence, contract logistics, and law and information technologies departments.

The operational excellence department is another part that provides another input of new investment decisions. Because they have in-depth knowledge about the numbers of the other projects within the organization or the logistics sectors, so they know clues and musts to manage an operation most effectively.

The contract logistics department consists of operation managers who run the operations. Therefore, they have indepth know-how about managing a warehouse and its members such as customers, personnel, and equipment to run any particular operation. The decision-makers and their weights on a project are stated in Table 4.

Step 1: Construct an IVN decision matrix for experts. The calculations' first step is determining the IVN decision matrix concerning each expert. This part of the study is asked for business development expertise, operational excellence, and contract logistics departments' members of the leading logistics company. They have evaluated every single alternative according to the criteria stated in Appendix 1. This evaluation has been done in terms of the IVN decision matrix scale stated in Table 3.

The IVN decision matrix, created after the evaluation of departments, is in Appendix 2.

Step 2: Construct aggregated IVN decision matrix. In this step of the calculations, the interval-valued neutrosophicweighted arithmetic averages of every single criterion are calculated using the IVNN of decision-makers. Equation 10 is used to obtain IVNN; these IVNN's are aggregated. The aggregated IVN decision matrix is in Appendix 3; for ease of use, we presented values of the first three alternatives.

Step 3: Construct the average solution matrix of criteria weights regarding experts. First of all, the decision-makers determine every single criterion's weights according to the scale stated in Table 3. Columns 2-4 of Appendix 4 state the criterion evaluation of decision-makers.

Step 4: Construct the matrix of average criteria weights. After decision-makers scored every single criterion, the average criteria weight matrix is constructed.

Step 5: Calculate PDA and NDA. In this step, every single criterion's PDA and NDA values are calculated for every 
single alternative. Criterion type, which can be either cost or benefit, is an essential input in this calculation. Appendix 4 displays PDA and NDA values in column 6 . The values are calculated by Eqs. 20 and 21.

Step 6: Weighted sum of PDA and NDA. Equations 22 and 23 are used for these calculations. Criterion weights are stated in Appendix 4. To reach weighted sums, we need to multiply the values in Appendix 4 with PDA and NDA matrix, which is calculated in Step 5. After this calculation $\mathrm{sp}_{\mathrm{n}}$ and $\mathrm{np}_{\mathrm{n}}$ values are found. The values for Abu Dhabi are in the last column of Appendix 4.

Step 7: Normalization of the $\mathrm{np}_{\mathrm{n}}$ and $\mathrm{sp}_{\mathrm{n}}$ values. In this step, normalized $\mathrm{np}_{\mathrm{n}}$ and $\mathrm{sp}_{\mathrm{n}}$ values are calculated for all alternatives using Eqs. 24 and 25. Table 5 states the values.

Step 8: Appraisal score calculation. In this step, all alternatives' appraisal scores $\left(\mathrm{as}_{\mathrm{n}}\right)$ have been calculated using Eq. 26. Appraisal scores $\left(\mathrm{as}_{\mathrm{n}}\right)$ are converted to ranking scores (RS) via the defuzzification technique, as seen in Table 5.

Table 5 nspn, nsnn, asn, and ranking values

\begin{tabular}{|c|c|c|c|}
\hline \# & & Values & RS \\
\hline & $\begin{array}{l}\mathrm{nsp}_{\mathrm{n}} \\
\mathrm{nsn}_{\mathrm{n}} \\
\mathrm{as}_{\mathrm{n}}\end{array}$ & $\begin{array}{l}{[(-21.45 ; 3.22),(0.01 ; 0.19),(0.00 ; 0.00)]} \\
{[(6.88 ;-0.11),(1.00 ; 0.93),(1.00 ; 1.00)]} \\
{[(66.52 ; 1.73),(0.00 ; 0.09),(0.00 ; 0.00)]}\end{array}$ & 16.78 \\
\hline $\mathrm{A}_{2}$ & $\begin{array}{l}\mathrm{nsp}_{\mathrm{n}} \\
\mathrm{nsn}_{\mathrm{n}} \\
\mathrm{as}_{\mathrm{n}}\end{array}$ & $\begin{array}{l}{[(-5.94 ; 3.31),(0.00 ; 0.10),(0.00 ; 0.00)]} \\
{[(18.66 ; 0.08),(1.00 ; 0.97),(1.00 ; 1.00)]} \\
{[(61.75 ; 1.56),(0.00 ; 0.05),(0.00 ; 0.00)]}\end{array}$ & 15.94 \\
\hline & $\begin{array}{l}\mathrm{nsp}_{\mathrm{n}} \\
\mathrm{nsn}_{\mathrm{n}} \\
\mathrm{as}_{\mathrm{n}}\end{array}$ & $\begin{array}{l}{[(-77.86 ; 2.61),(0.01 ; 0.26),(0.00 ; 0.00)]} \\
{[(0.36 ;-0.18),(1.00 ; 0.91),(1.00 ; 1.00)]} \\
{[(-24.73 ; 1.45),(0.00 ; 0.12),(0.00 ; 0.00)]}\end{array}$ & -5.00 \\
\hline $\mathrm{A}_{4}$ & $\begin{array}{l}\operatorname{nsp}_{n} \\
\mathrm{nsn}_{\mathrm{n}} \\
\mathrm{as}_{\mathrm{n}}\end{array}$ & $\begin{array}{l}{[(-34.14 ; 3.06),(0.01 ; 0.22),(0.00 ; 0.00)]} \\
{[(3.42 ;-0.15),(1.00 ; 0.92),(1.00 ; 1.00)]} \\
{[(43.00 ; 1.69),(0.00 ; 0.10),(0.00 ; 0.00)]}\end{array}$ & 11.06 \\
\hline 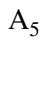 & $\begin{array}{l}\mathrm{nsp}_{\mathrm{n}} \\
\mathrm{nsn}_{\mathrm{n}} \\
\mathrm{as}_{\mathrm{n}}\end{array}$ & $\begin{array}{l}{[(-70.05 ; 2.34),(0.04 ; 0.64),(0.00 ; 0.00)]} \\
{[(1.03 ;-0.17),(0.99 ; 0.78),(1.00 ; 1.00)]} \\
{[(1.56 ; 1.28),(0.02 ; 0.25),(0.00 ; 0.00)]}\end{array}$ & 1.05 \\
\hline$A_{6}$ & $\begin{array}{l}\mathrm{nsp}_{\mathrm{n}} \\
\mathrm{nsn}_{\mathrm{n}} \\
\mathrm{as}_{\mathrm{n}}\end{array}$ & $\begin{array}{l}{[(-8.58 ; 3.30),(0.00 ; 0.10),(0.00 ; 0.00)]} \\
{[(14.88 ; 0.01),(1.00 ; 0.97),(1.00 ; 1.00)]} \\
{[(67.00 ; 1.65),(0.00 ; 0.05),(0.00 ; 0.00)]}\end{array}$ & 17.23 \\
\hline - & $\begin{array}{l}\operatorname{nsp}_{n} \\
\operatorname{nsn}_{n} \\
\operatorname{as}_{n}\end{array}$ & $\begin{array}{l}{[(-46.63 ; 2.90),(0.01 ; 0.34),(0.00 ; 0.00)]} \\
{[(1.93 ;-0.16),(0.99 ; 0.88),(1.00 ; 1.00)]} \\
{[(22.59 ; 1.60),(0.01 ; 0.15),(0.00 ; 0.00)]}\end{array}$ & 6.03 \\
\hline 8 & $\begin{array}{l}\mathrm{nsp}_{\mathrm{n}} \\
\mathrm{nsn}_{\mathrm{n}} \\
\mathrm{as}_{\mathrm{n}}\end{array}$ & $\begin{array}{l}{[(-28.34 ; 3.13),(0.01 ; 0.29),(0.00 ; 0.00)]} \\
{[(4.21 ;-0.15),(1.00 ; 0.90),(1.00 ; 1.00)]} \\
{[(47.63 ; 1.72),(0.01 ; 0.13),(0.00 ; 0.00)]}\end{array}$ & 11.97 \\
\hline 9 & $\begin{array}{l}\operatorname{nsp}_{n} \\
\mathrm{nsn}_{\mathrm{n}} \\
\mathrm{as}_{\mathrm{n}}\end{array}$ & $\begin{array}{l}{[(-54.91 ; 2.72),(0.02 ; 0.38),(0.00 ; 0.00)]} \\
{[(1.36 ;-0.17),(0.99 ; 0.87),(1.00 ; 1.00)]} \\
{[(10.65 ; 1.50),(0.01 ; 0.17),(0.00 ; 0.00)]}\end{array}$ & 3.23 \\
\hline$A_{10}$ & $\begin{array}{l}\operatorname{nsp}_{n} \\
\operatorname{nsn}_{n} \\
\operatorname{as}_{n}\end{array}$ & $\begin{array}{l}{[(-66.59 ; 2.58),(0.02 ; 0.39),(0.00 ; 0.00)]} \\
{[(1.34 ;-0.17),(0.99 ; 0.86),(1.00 ; 1.00)]} \\
{[(12.06 ; 1.42),(0.01 ; 0.17),(0.00 ; 0.00)]}\end{array}$ & 3.53 \\
\hline$A_{11}$ & $\begin{array}{l}\mathrm{nsp}_{\mathrm{n}} \\
\mathrm{nsn}_{\mathrm{n}} \\
\mathrm{as}_{\mathrm{n}}\end{array}$ & $\begin{array}{l}{[(-55.35 ; 2.84),(0.01 ; 0.35),(0.00 ; 0.00)]} \\
{[(0.93 ;-0.17),(1.00 ; 0.88),(1.00 ; 1.00)]} \\
{[(-1.52 ; 1.58),(0.01 ; 0.15),(0.00 ; 0.00)]}\end{array}$ & 0.4 \\
\hline
\end{tabular}

Step 9: Ranking alternatives. In the last phase of the technique, alternatives are ranked according to decreasing score value. Table 5 shows Riyadh as the top-ranked city among the other options with an RS of 17.23.

\section{Conclusion}

Logistics is one of the essential stones of the supply chain. Because to supply, a product or service must be taken from one place to another. It also needs to be stored and handled where it is taken. Since companies are in serious competition to increase their service quality, concepts such as global supply chain and logistics management are gaining importance day by day. In doing so, they focus on keeping their costs constant or reducing their costs. This situation forces companies to look for new ways and become more innovative. Otherwise, the companies that continue their business in the traditional methods count on the spot, and many are sinking, because the service level is low.

Information became more accessible than before after the internet gained serious importance and became a part of people's lives. With the storage and analysis of information, companies and institutions were able to analyze their processes, measure their quality, and identify disrupted processes.

Analyzes were carried out on ensuring an efficient cold chain just like in other sectors, because temperature-sensitive products had to be transported from regions where production is high to regions where production is less before their shelf life is completed. With global warming awareness, waste came back to the schedule.

After years of waste and consumption craze in today's world, savings and sustainability are no longer at the forefront. Countries, organizations, companies, and even families are focused on what is sustainable and stays fresh up to the end. And this rate is expected to increase gradually.

This study examines cold chain logistics. It also mentions the differences from other logistics methods. However, its primary purpose is to explore the cold chain's storage and warehousing aspects. Studies and analysis show that if the chain is adequately protected, the products do not fill their shelf life, reaching the end consumer healthily and freshly. Temperature-controlled storage, handling, and shipping are needed to construct the cold chain logistics operations under optimum conditions. The transportation process should also be done at the right temperature with cold chain vehicles.

Providing all these conditions may be too costly for a company that manufactures or markets. At this point, thirdparty companies that specialize in a particular area come into play. These companies are named 3PL and 4PL in the logistics industry. These companies are named 3PL and 4PL in the logistics sector, and they carry out the logistics 
RS

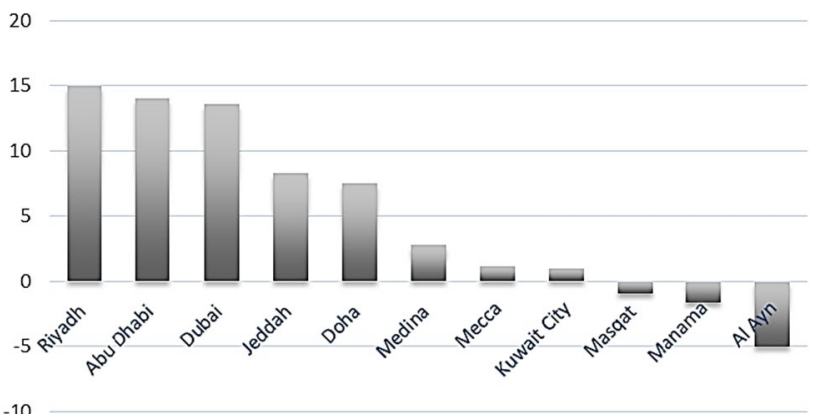

Fig. 3 Ranking scores of alternatives

activities of your company according to a specific contract. If a company fails to manage its logistics processes well, it may decide to outsource this process to any third-party logistics supplier specialized in the field. That is why, the warehouse location selection of logistics service providers is a crucial decision problem [67]. Because this kind of investment decision is costly and hard to repair, these decisions are also among the most critical strategic decisions for companies (Fig. 3).

In this study, the selection of cold chain warehouse location for third-party logistics suppliers was discussed. First of all, the concepts familiar with cold chain and 3PL were reviewed. In the literature review part, the subjects such as supply chain, warehouse location selection, cold chain logistics, 3PL, and supply chain management were investigated.

In an environment where the concept of choice exists, there has to be a decision-making process. It has been determined that there are many decision-making methods after the result of scientific studies carried out for years. In this study, the IVN EDAS MCDM technique was used. If we want to decide something, we should have alternatives, and alternatives of this study consist of cities that are ports and commercial centers in Arabian Gulf countries. The reason for choosing this region is that its climate is hot all-yearround, so the area needs efficient cold chain management. Also, this region has high consumption, and most of the goods are imported from another country, since it is hard to produce because of climate conditions.

In the experimental analysis part, alternative cities are evaluated according to IVN EDAS rules, and it is seen that this method is useful in solving that kind of selection problems. Business Development, Operational Excellence, and Contract Logistics departments of one of Turkey's leading logistics company are asked for criteria evaluation. According to these decision-makers' evaluations, IVNF EDAS calculations have been done. We used the IVNF EDAS method in this study, because we wanted to consider the aspect of falsity, indeterminacy, and trueness of decision-makers.
Table 6 Attribute rankings of other EDAS techniques

\begin{tabular}{llll}
\hline & EDAS & F- EDAS & IF-EDAS \\
\hline $\mathrm{A}_{1}$ & 2 & 2 & 2 \\
$\mathrm{~A}_{2}$ & 3 & 4 & 4 \\
$\mathrm{~A}_{3}$ & 11 & 11 & 11 \\
$\mathrm{~A}_{4}$ & 5 & 5 & 6 \\
$\mathrm{~A}_{5}$ & 10 & 10 & 10 \\
$\mathrm{~A}_{6}$ & 1 & 1 & 1 \\
$\mathrm{~A}_{7}$ & 6 & 6 & 5 \\
$\mathrm{~A}_{8}$ & 4 & 3 & 3 \\
$\mathrm{~A}_{9}$ & 7 & 8 & 8 \\
$\mathrm{~A}_{10}$ & 8 & 7 & 7 \\
$\mathrm{~A}_{11}$ & 9 & 9 & 9 \\
\hline
\end{tabular}

As a result of these calculations, Riyadh, Abu Dhabi, and Dubai have been the top three ranked cities. The cities which we consider vital at the early stages of the study come first. Because it is evident that criteria selection is the essential key for this project, these three cities are better than the other cities in terms of overall criteria. Doha was another alternative, but the score came lower due to political disputes in the region. The decision-makers expected to provide service to the Gulf region's top country.

Considering all this, Abu Dhabi, Dubai, and Riyadh are the cities with the highest trade in the region. They are close to potential customers and potential markets. When we compare these three cities with the other ones, their geographical positions, political situations, or warehouse facilities are worse. Therefore, the logistics company can choose one of three high ranked cities, where Riyadh is the best option.

On the other hand, to comprehend how other EDAS methods affect the attributes ranking, we have processed the same data using EDAS, Fuzzy EDAS, and Intuitionistic Fuzzy EDAS techniques. When we use these techniques, the attributes' ranking differs, as seen in Table 6. We can conclude that F-EDAS and IF-EDAS are most likely to have similar rankings when classical EDAS have considerably different results.

Based on their background and their responsibility, it is evident that $\mathrm{DM}_{1}$ is more concerned about Macro-Environment $\left(\mathrm{C}_{4}\right)$ criterion. $\mathrm{DM}_{2}$ would be worried about $\operatorname{Cost}\left(\mathrm{C}_{2}\right)$, and $\mathrm{DM}_{3}$ would care about Location $\left(\mathrm{C}_{1}\right)$, Warehouse Facilities $\left(\mathrm{C}_{3}\right)$, and Cooling Facilities $\left(\mathrm{C}_{5}\right)$. This is also true that $\mathrm{C}_{4}$ and $\mathrm{C}_{5}$ would play an important role in sales efforts, which are the primary responsibilities of DM1. When we changed the weights stated in Table 4, we have observed that $\mathrm{DM}_{2}$ and $\mathrm{DM}_{3}$ have more effect on alternative rankings than $\mathrm{DM}_{1}$. This dominance is both valid for unique and pairwise comparisons. The $\mathrm{DM}_{2}+\mathrm{DM}_{3}$ pair has a higher degree of impact over attributes than the $\mathrm{DM}_{1}+\mathrm{DM}_{2}$ and $\mathrm{DM}_{1}+\mathrm{DM}_{3}$ pairs. A unit scale change effect in the $\mathrm{DM}_{2}+\mathrm{DM}_{3}$ pair is 0.743 
RS point, while it is 0.335 and 0.285 for the $\mathrm{DM}_{1}+\mathrm{DM}_{2}$ and $\mathrm{DM}_{1}+\mathrm{DM}_{3}$ pairs, respectively.

Regarding the criteria weights, Location $\left(\mathrm{C}_{1}\right)$, Warehouse Facilities $\left(\mathrm{C}_{3}\right)$, and Cooling Facilities $\left(\mathrm{C}_{5}\right)$ have more impact on the rankings. When we change the average weights by one scale level, while the decision matrix remains the same, ranking scores of options with higher evaluations of location and facility attributes augment far more compared to Cost $\left(\mathrm{C}_{1}\right)$ and Macro-Environment $\left(\mathrm{C}_{4}\right)$ attributes. We can conclude that if one site wants to be an attractive option for cold chain logistics, it needs to have a better location and better services than its rivals.

As for future studies related to this study, the followings can be done, and results can be applied to any company.
- Different departments can be used, and their effects can be analyzed.

- Different weights can be used for departments, and results can be analyzed.

- Sensitivity analysis can be done.

- The same study can be done for a different region, for example, South Africa.

\section{Appendix 1}

\section{See Table 7.}

Table 7 Criteria and sub-criteria, and their correspondent references

\begin{tabular}{|c|c|c|c|c|}
\hline$\#$ & Criteria & \# & Sub-criteria & Covered by \\
\hline \multirow[t]{6}{*}{$\mathrm{C}_{1}$} & \multirow[t]{6}{*}{ Location } & $\mathrm{C}_{11}$ & Proximity to potential markets & $\begin{array}{l}\text { Ozcan et al. (2011), Roh et al. (2013), Dey et al. (2015), Oztaysi et al. (2016) } \\
\text { Dey et al. (2016) }\end{array}$ \\
\hline & & $\mathrm{C}_{12}$ & Proximity to producers & Ozcan et al. (2011), Asrafzadeh et al. (2012) \\
\hline & & $\mathrm{C}_{13}$ & $\begin{array}{l}\text { Proximity to main roads, sea- } \\
\text { ports, and airports }\end{array}$ & $\begin{array}{l}\text { Kaboli et al. (2007), Demirel et al. (2010), Dey et al. (2013), Roh et al. } \\
\text { (2013), Dey. et al. (2015), Oztaysi et al. (2016) }\end{array}$ \\
\hline & & $\mathrm{C}_{14}$ & Proximity to forwarding agents & ROH et al. (2013) \\
\hline & & $\mathrm{C}_{15}$ & Climate conditions & $\begin{array}{l}\text { Kaboli et al. (2007), Asrafzadeh et al. (2012), Dey et al. (2013), Oztaysi et al. } \\
\text { (2015), Oztaysi et al. (2016), Raut et al. (2017) }\end{array}$ \\
\hline & & $\mathrm{C}_{16}$ & Availability of skilled workforce & $\begin{array}{l}\text { Chu et al. (2002), Demirel. et al. (2010), Asrafzadeh et al. (2012), Oztaysi } \\
\text { et al. (2015), Oztaysi et al. (2016), Raut et al. (2017) }\end{array}$ \\
\hline \multirow[t]{7}{*}{$\mathrm{C}_{2}$} & \multirow[t]{7}{*}{ Cost } & $\mathrm{C}_{21}$ & Storage cost & Roh et al. (2013), Oztaysi et al. (2016) \\
\hline & & $\mathrm{C}_{22}$ & Investment cost & Chu (2002), Dey et al. (2013) \\
\hline & & $\mathrm{C}_{23}$ & Rental cost & Asrafzadeh et al. (2012), Roh et al. (2013), Oztaysi et al. (2016) \\
\hline & & $\mathrm{C}_{24}$ & Labor cost & $\begin{array}{l}\text { Demirel et al. (2010), Asrafzadeh et al. (2012), Roh et al. (2013), Oztaysi } \\
\text { et al. (2016) }\end{array}$ \\
\hline & & $\mathrm{C}_{25}$ & Energy cost & This study \\
\hline & & $\mathrm{C}_{26}$ & Tax cost & Demirel et al. (2010) \\
\hline & & $\mathrm{C}_{27}$ & Transportation cost & Asrafzadeh et al. (2012), Raut et al. (2017) \\
\hline \multirow[t]{9}{*}{$\mathrm{C}_{3}$} & \multirow[t]{9}{*}{ Warehouse Facilities } & $\mathrm{C}_{31}$ & Structural suitability & Demirel et al. (2010) \\
\hline & & $\mathrm{C}_{32}$ & Parking facilities & Raut et al. (2017) \\
\hline & & $\mathrm{C}_{33}$ & Hygiene facilities & This study \\
\hline & & $\mathrm{C}_{34}$ & Hydraulic ramp facility & This study \\
\hline & & $\mathrm{C}_{35}$ & Adequate truck manoeuvre field & This study \\
\hline & & $\mathrm{C}_{36}$ & Security & Oztaysi et al. (2016) \\
\hline & & $\mathrm{C}_{37}$ & Stock holding capacity & Özcan et al. (2011) \\
\hline & & $\mathrm{C}_{38}$ & Separated waste field & Raut et al. (2017) \\
\hline & & $\mathrm{C}_{39}$ & Adequate IT/network system & $\begin{array}{l}\text { Demirel et al. (2010), Asrafzadeh et al. (2012), Oztaysi et al. (2016), Singh } \\
\text { et al. (2017), Raut et al. (2017) }\end{array}$ \\
\hline \multirow[t]{2}{*}{$\mathrm{C}_{4}$} & \multirow[t]{2}{*}{ Macro-Environment } & $\mathrm{C}_{41}$ & Government policies & $\begin{array}{l}\text { Demirel et al. (2010), Roh et al. (2013), Dey et al. (2015), Oztaysi et al. } \\
\text { (2016), Raut et al. (2017) }\end{array}$ \\
\hline & & $\mathrm{C}_{42}$ & Industrial regulations and laws & $\begin{array}{l}\text { Demirel et al. (2010), Roh et al. (2013), Dey et al. (2015), Oztaysi et al. } \\
\text { (2016), Raut et al. (2017) }\end{array}$ \\
\hline \multirow[t]{3}{*}{$\mathrm{C}_{5}$} & \multirow[t]{3}{*}{ Cooling Facilities } & $\mathrm{C}_{51}$ & Cold storage & This study \\
\hline & & $\mathrm{C}_{52}$ & Cold transport & This study \\
\hline & & $\mathrm{C}_{53}$ & Cold processing & This study \\
\hline
\end{tabular}




\section{Appendix 2}

See Table 8 .

Table 8 Decision matrix with respect to $\mathrm{DM}_{1}$ (w: \%40)

\begin{tabular}{|c|c|c|c|c|c|c|c|c|c|c|c|c|}
\hline $\mathrm{DM}_{1}$ & $\begin{array}{l}\text { W: } 0.40 \\
\text { Type }\end{array}$ & $\begin{array}{l}\text { Abu Dhabi } \\
A_{1}\end{array}$ & $\begin{array}{l}\text { Dubai } \\
\mathrm{A}_{2}\end{array}$ & $\begin{array}{l}\text { Al Ayn } \\
\mathrm{A}_{3}\end{array}$ & $\begin{array}{l}\text { Doha } \\
\mathrm{A}_{4}\end{array}$ & $\begin{array}{l}\text { Manama } \\
\mathrm{A}_{5}\end{array}$ & $\begin{array}{l}\text { Riyadh } \\
\mathrm{A}_{6}\end{array}$ & $\begin{array}{l}\text { Medina } \\
\mathrm{A}_{7}\end{array}$ & $\begin{array}{l}\text { Jeddah } \\
\mathrm{A}_{8}\end{array}$ & $\begin{array}{l}\text { Mecca } \\
\mathrm{A}_{9}\end{array}$ & $\begin{array}{l}\text { Kuwait City } \\
\mathrm{A}_{10}\end{array}$ & $\begin{array}{l}\text { Masqat } \\
\mathrm{A}_{11}\end{array}$ \\
\hline $\mathrm{C}_{11}$ & Benefit & $\mathrm{H}$ & $\mathrm{VH}$ & $\mathrm{L}$ & $\mathrm{H}$ & $\mathrm{H}$ & $\mathrm{VH}$ & BA & A & BA & A & VL \\
\hline $\mathrm{C}_{12}$ & Benefit & $\mathrm{H}$ & $\mathrm{VH}$ & $\mathrm{L}$ & $\mathrm{H}$ & AA & $\mathrm{VH}$ & $\mathrm{L}$ & AA & $\mathrm{L}$ & AA & $\mathrm{L}$ \\
\hline $\mathrm{C}_{13}$ & Benefit & $\mathrm{VH}$ & VH & $\mathrm{BA}$ & $\mathrm{VH}$ & AA & $\mathrm{VH}$ & A & $\mathrm{VH}$ & $\mathrm{L}$ & $\mathrm{H}$ & $\mathrm{L}$ \\
\hline $\mathrm{C}_{14}$ & Benefit & $\mathrm{VH}$ & $\mathrm{VH}$ & A & $\mathrm{VH}$ & $\mathrm{H}$ & $\mathrm{VH}$ & A & $\mathrm{VH}$ & A & $\mathrm{H}$ & $\mathrm{BA}$ \\
\hline $\mathrm{C}_{15}$ & Benefit & A & A & A & A & A & BA & A & A & A & A & A \\
\hline $\mathrm{C}_{16}$ & Benefit & $\mathrm{H}$ & $\mathrm{H}$ & VL & $\mathrm{H}$ & A & $\mathrm{H}$ & $\mathrm{L}$ & A & BA & AA & VL \\
\hline $\mathrm{C}_{21}$ & Cost & $\mathrm{H}$ & $\mathrm{H}$ & $\mathrm{CL}$ & VH & AA & VH & BA & $\mathrm{H}$ & VL & AA & $\mathrm{CL}$ \\
\hline $\mathrm{C}_{22}$ & Cost & $\mathrm{VH}$ & VH & $\mathrm{L}$ & $\mathrm{VH}$ & AA & $\mathrm{VH}$ & AA & $\mathrm{H}$ & AA & AA & $\mathrm{L}$ \\
\hline $\mathrm{C}_{23}$ & Cost & $\mathrm{H}$ & $\mathrm{H}$ & VL & $\mathrm{H}$ & A & $\mathrm{H}$ & AA & AA & A & AA & $\mathrm{L}$ \\
\hline $\mathrm{C}_{24}$ & Cost & $\mathrm{H}$ & $\mathrm{H}$ & BA & $\mathrm{H}$ & BA & $\mathrm{H}$ & AA & AA & A & AA & BA \\
\hline $\mathrm{C}_{25}$ & Cost & A & A & AA & A & AA & A & AA & AA & A & A & AA \\
\hline $\mathrm{C}_{26}$ & Cost & A & A & AA & A & AA & A & A & AA & A & A & AA \\
\hline $\mathrm{C}_{27}$ & Cost & $\mathrm{H}$ & AA & A & AA & AA & $\mathrm{AA}$ & A & AA & A & AA & A \\
\hline $\mathrm{C}_{31}$ & Benefit & $\mathrm{VH}$ & $\mathrm{VH}$ & BA & $\mathrm{H}$ & A & $\mathrm{AA}$ & A & A & A & A & A \\
\hline $\mathrm{C}_{32}$ & Benefit & AA & $\mathrm{H}$ & A & A & A & $\mathrm{VH}$ & $\mathrm{VH}$ & $\mathrm{H}$ & $\mathrm{VH}$ & AA & $\mathrm{AA}$ \\
\hline $\mathrm{C}_{33}$ & Benefit & AA & $\mathrm{H}$ & AA & A & A & AA & A & A & BA & A & A \\
\hline $\mathrm{C}_{34}$ & Benefit & $\mathrm{H}$ & $\mathrm{H}$ & BA & AA & BA & $\mathrm{H}$ & BA & AA & BA & A & $\mathrm{VH}$ \\
\hline $\mathrm{C}_{35}$ & Benefit & AA & $\mathrm{H}$ & VH & BA & BA & $\mathrm{H}$ & $\mathrm{H}$ & AA & $\mathrm{H}$ & BA & AA \\
\hline $\mathrm{C}_{36}$ & Benefit & AA & $\mathrm{H}$ & A & $\mathrm{H}$ & A & AA & A & AA & BA & $\mathrm{AA}$ & BA \\
\hline $\mathrm{C}_{37}$ & Benefit & AA & $\mathrm{H}$ & A & BA & BA & $\mathrm{VH}$ & AA & AA & $\mathrm{AA}$ & BA & A \\
\hline $\mathrm{C}_{38}$ & Benefit & $\mathrm{H}$ & $\mathrm{CH}$ & $\mathrm{CL}$ & AA & VL & $\mathrm{VH}$ & AA & $\mathrm{AA}$ & AA & AA & A \\
\hline $\mathrm{C}_{39}$ & Benefit & $\mathrm{H}$ & $\mathrm{H}$ & BA & $\mathrm{H}$ & A & $\mathrm{H}$ & VL & AA & VL & BA & BA \\
\hline $\mathrm{C}_{41}$ & Benefit & $\mathrm{H}$ & $\mathrm{H}$ & $\mathrm{H}$ & AA & A & AA & AA & AA & AA & AA & $\mathrm{H}$ \\
\hline $\mathrm{C}_{42}$ & Benefit & $\mathrm{H}$ & $\mathrm{H}$ & $\mathrm{H}$ & AA & A & $\mathrm{AA}$ & AA & AA & AA & AA & $\mathrm{H}$ \\
\hline $\mathrm{C}_{51}$ & Benefit & $\mathrm{VH}$ & $\mathrm{CH}$ & $\mathrm{L}$ & AA & AA & $\mathrm{CH}$ & $\mathrm{CH}$ & AA & $\mathrm{H}$ & AA & $\mathrm{AA}$ \\
\hline $\mathrm{C}_{52}$ & Benefit & VH & VH & BA & $\mathrm{H}$ & $\mathrm{H}$ & $\mathrm{VH}$ & $\mathrm{VH}$ & $\mathrm{H}$ & $\mathrm{AA}$ & $\mathrm{H}$ & AA \\
\hline $\mathrm{C}_{53}$ & Benefit & $\mathrm{H}$ & $\mathrm{H}$ & A & $\mathrm{H}$ & AA & $\mathrm{H}$ & A & $\mathrm{CH}$ & A & AA & BA \\
\hline
\end{tabular}




\section{Appendix 3}

\section{See Table 9.}

Table 9 Aggregated IVN decision matrix for $\mathrm{A}_{1}, \mathrm{~A}_{2}$, and $\mathrm{A}_{3}$

\begin{tabular}{|c|c|c|c|c|}
\hline Criterion & Type & Abu Dhabi- $\mathrm{A}_{1}$ & Dubai- $\mathrm{A}_{2}$ & Al Ayn- $\mathrm{A}_{3}$ \\
\hline $\mathrm{C}_{11}$ & Benefit & {$[(0.71 ; 0.82),(0.32 ; 0.42),(0.29 ; 0.39)]$} & {$[(0.75 ; 0.85),(0.25 ; 0.35),(0.25 ; 0.35)]$} & $\begin{array}{l}{[(0.35 ; 0.45),(0.45 ; 0.55),(0.65 ;} \\
\quad 0.75)]\end{array}$ \\
\hline $\mathrm{C}_{12}$ & Benefit & {$[(0.66 ; 0.76),(0.4 ; 0.5),(0.34 ; 0.44)]$} & {$[(0.76 ; 0.87),(0.26 ; 0.36),(0.24 ; 0.34)]$} & $\begin{array}{l}{[(0.38 ; 0.48),(0.48 ; 0.58),(0.62 ;} \\
\quad 0.72)]\end{array}$ \\
\hline $\mathrm{C}_{13}$ & Benefit & {$[(0.76 ; 0.87),(0.26 ; 0.36),(0.24 ; 0.34)]$} & {$[(0.79 ; 0.89),(0.21 ; 0.32),(0.21 ; 0.32)]$} & $\begin{array}{l}{[(0.42 ; 0.52),(0.52 ; 0.62),(0.58 ;} \\
\quad 0.68)]\end{array}$ \\
\hline $\mathrm{C}_{14}$ & Benefit & {$[(0.72 ; 0.83),(0.3 ; 0.4),(0.28 ; 0.38)]$} & {$[(0.76 ; 0.87),(0.26 ; 0.36),(0.24 ; 0.34)]$} & $\begin{array}{l}{[(0.52 ; 0.59),(0.62 ; 0.72),(0.48 ;} \\
\quad 0.58)]\end{array}$ \\
\hline $\mathrm{C}_{15}$ & Benefit & {$[(0.55 ; 0.6),(0.65 ; 0.75),(0.45 ; 0.55)]$} & {$[(0.55 ; 0.6),(0.65 ; 0.75),(0.45 ; 0.55)]$} & $\begin{array}{l}{[(0.55 ; 0.60),(0.65 ; 0.75),(0.45 ;} \\
0.55)]\end{array}$ \\
\hline $\mathrm{C}_{16}$ & Benefit & {$[(0.65 ; 0.75),(0.45 ; 0.55),(0.35 ; 0.45)]$} & {$[(0.68 ; 0.79),(0.38 ; 0.48),(0.32 ; 0.42)]$} & $\begin{array}{l}{[(0.35 ; 0.45),(0.43 ; 0.53),(0.65} \\
\quad 0.76)]\end{array}$ \\
\hline $\mathrm{C}_{21}$ & Cost & {$[(0.66 ; 0.76),(0.4 ; 0.5),(0.34 ; 0.44)]$} & {$[(0.71 ; 0.82),(0.32 ; 0.42),(0.29 ; 0.39)]$} & $\begin{array}{l}{[(0.24 ; 0.35),(0.27 ; 0.38),(0.76} \\
\quad 0.86)]\end{array}$ \\
\hline $\mathrm{C}_{22}$ & Cost & {$[(0.79 ; 0.89),(0.21 ; 0.32),(0.21 ; 0.32)]$} & {$[(0.75 ; 0.85),(0.25 ; 0.35),(0.25 ; 0.35)]$} & $\begin{array}{l}{[(0.38 ; 0.48),(0.48 ; 0.58),(0.62 ;} \\
\quad 0.72)]\end{array}$ \\
\hline $\mathrm{C}_{23}$ & Cost & {$[(0.68 ; 0.79),(0.38 ; 0.48),(0.32 ; 0.42)]$} & {$[(0.68 ; 0.79),(0.38 ; 0.48),(0.32 ; 0.42)]$} & $\begin{array}{l}{[(0.28 ; 0.38),(0.38 ; 0.48),(0.72 ;} \\
\quad 0.82)]\end{array}$ \\
\hline $\mathrm{C}_{24}$ & Cost & {$[(0.68 ; 0.79),(0.38 ; 0.48),(0.32 ; 0.42)]$} & {$[(0.65 ; 0.75),(0.45 ; 0.55),(0.35 ; 0.45)]$} & $\begin{array}{l}{[(0.48 ; 0.57),(0.58 ; 0.68),(0.52 ;} \\
\quad 0.62)]\end{array}$ \\
\hline $\mathrm{C}_{25}$ & Cost & {$[(0.52 ; 0.59),(0.62 ; 0.72),(0.48 ; 0.58)]$} & {$[(0.52 ; 0.59),(0.62 ; 0.72),(0.48 ; 0.58)]$} & $\begin{array}{l}{[(0.55 ; 0.64),(0.58 ; 0.68),(0.45 ;} \\
\quad 0.55)]\end{array}$ \\
\hline $\mathrm{C}_{26}$ & Cost & {$[(0.55 ; 0.62),(0.62 ; 0.72),(0.45 ; 0.55)]$} & {$[(0.55 ; 0.62),(0.62 ; 0.72),(0.45 ; 0.55)]$} & $\begin{array}{l}{[(0.55 ; 0.64),(0.58 ; 0.68),(0.45 ;} \\
\quad 0.55)]\end{array}$ \\
\hline $\mathrm{C}_{27}$ & Cost & {$[(0.71 ; 0.82),(0.32 ; 0.42),(0.29 ; 0.39)]$} & {$[(0.61 ; 0.71),(0.49 ; 0.59),(0.39 ; 0.49)]$} & $\begin{array}{l}{[(0.55 ; 0.62),(0.62 ; 0.72),(0.45 ;} \\
\quad 0.55)]\end{array}$ \\
\hline $\mathrm{C}_{31}$ & Benefit & {$[(0.69 ; 0.8),(0.36 ; 0.46),(0.31 ; 0.41)]$} & {$[(0.72 ; 0.83),(0.3 ; 0.4),(0.28 ; 0.38)]$} & $\begin{array}{l}{[(0.48 ; 0.57),(0.58 ; 0.68),(0.52 ;} \\
\quad 0.62)]\end{array}$ \\
\hline $\mathrm{C}_{32}$ & Benefit & {$[(0.55 ; 0.65),(0.55 ; 0.65),(0.45 ; 0.55)]$} & {$[(0.62 ; 0.72),(0.48 ; 0.58),(0.38 ; 0.48)]$} & $\begin{array}{l}{[(0.55 ; 0.62),(0.62 ; 0.72),(0.45 ;} \\
0.55)]\end{array}$ \\
\hline $\mathrm{C}_{33}$ & Benefit & {$[(0.55 ; 0.64),(0.58 ; 0.68),(0.45 ; 0.55)]$} & {$[(0.59 ; 0.69),(0.51 ; 0.61),(0.41 ; 0.51)]$} & $\begin{array}{l}{[(0.55 ; 0.62),(0.61 ; 0.71),(0.45 ;} \\
\quad 0.55)]\end{array}$ \\
\hline $\mathrm{C}_{34}$ & Benefit & {$[(0.62 ; 0.72),(0.48 ; 0.58),(0.38 ; 0.48)]$} & {$[(0.68 ; 0.79),(0.38 ; 0.48),(0.32 ; 0.42)]$} & $\begin{array}{l}{[(0.54 ; 0.66),(0.41 ; 0.51),(0.46 ;} \\
0.56)]\end{array}$ \\
\hline $\mathrm{C}_{35}$ & Benefit & {$[(0.55 ; 0.65),(0.55 ; 0.65),(0.45 ; 0.55)]$} & {$[(0.65 ; 0.75),(0.45 ; 0.55),(0.35 ; 0.45)]$} & $\begin{array}{l}{[(0.70 ; 0.81),(0.32 ; 0.42),(0.30} \\
\quad 0.40)]\end{array}$ \\
\hline $\mathrm{C}_{36}$ & Benefit & {$[(0.58 ; 0.67),(0.54 ; 0.65),(0.42 ; 0.52)]$} & {$[(0.66 ; 0.76),(0.4 ; 0.5),(0.34 ; 0.44)]$} & $\begin{array}{l}{[(0.52 ; 0.60),(0.59 ; 0.69),(0.48 ;} \\
0.58)]\end{array}$ \\
\hline $\mathrm{C}_{37}$ & Benefit & {$[(0.55 ; 0.65),(0.55 ; 0.65),(0.45 ; 0.55)]$} & {$[(0.65 ; 0.75),(0.45 ; 0.55),(0.35 ; 0.45)]$} & $\begin{array}{l}{[(0.48 ; 0.54),(0.54 ; 0.64),(0.52 ;} \\
\quad 0.63)]\end{array}$ \\
\hline $\mathrm{C}_{38}$ & Benefit & {$[(0.65 ; 0.75),(0.45 ; 0.55),(0.35 ; 0.45)]$} & {$[(0.81 ; 0.92),(0.21 ; 0.32),(0.19 ; 0.3)]$} & $\begin{array}{l}{[(0.21 ; 0.31),(0.25 ; 0.36),(0.79 ;} \\
\quad 0.89)]\end{array}$ \\
\hline $\mathrm{C}_{39}$ & Benefit & {$[(0.62 ; 0.72),(0.48 ; 0.58),(0.38 ; 0.48)]$} & {$[(0.71 ; 0.82),(0.32 ; 0.42),(0.29 ; 0.39)]$} & $\begin{array}{l}{[(0.42 ; 0.52),(0.52 ; 0.62),(0.58 ;} \\
\quad 0.68)]\end{array}$ \\
\hline $\mathrm{C}_{41}$ & Benefit & {$[(0.62 ; 0.72),(0.48 ; 0.58),(0.38 ; 0.48)]$} & {$[(0.62 ; 0.72),(0.48 ; 0.58),(0.38 ; 0.48)]$} & $\begin{array}{l}{[(0.62 ; 0.72),(0.48 ; 0.58),(0.38 ;} \\
\quad 0.48)]\end{array}$ \\
\hline $\mathrm{C}_{42}$ & Benefit & {$[(0.62 ; 0.72),(0.48 ; 0.58),(0.38 ; 0.48)]$} & {$[(0.62 ; 0.72),(0.48 ; 0.58),(0.38 ; 0.48)]$} & $\begin{array}{l}{[(0.62 ; 0.72),(0.48 ; 0.58),(0.38 ;} \\
\quad 0.48)]\end{array}$ \\
\hline $\mathrm{C}_{51}$ & Benefit & {$[(0.76 ; 0.87),(0.26 ; 0.36),(0.24 ; 0.34)]$} & {$[(0.83 ; 0.93),(0.17 ; 0.28),(0.17 ; 0.28)]$} & $\begin{array}{l}{[(0.35 ; 0.46),(0.44 ; 0.54),(0.65 ;} \\
\quad 0.75)]\end{array}$ \\
\hline $\mathrm{C}_{52}$ & Benefit & {$[(0.76 ; 0.87),(0.26 ; 0.36),(0.24 ; 0.34)]$} & {$[(0.79 ; 0.89),(0.21 ; 0.32),(0.21 ; 0.32)]$} & {$[(0.42 ; 0.52),(0.52 ; 0.62),(0.58 ; 0.68)]$} \\
\hline $\mathrm{C}_{53}$ & Benefit & {$[(0.68 ; 0.79),(0.38 ; 0.48),(0.32 ; 0.42)]$} & {$[(0.75 ; 0.87),(0.27 ; 0.38),(0.25 ; 0.35)]$} & $\begin{array}{l}{[(0.47 ; 0.54),(0.550 .65),(0.53 ;} \\
0.63)]\end{array}$ \\
\hline
\end{tabular}




\section{Appendix 4}

\section{See Table 10.}

Table 10 Criteria scores determined by DMs and PDA, NDA, $\mathrm{sp}_{\mathrm{n}}$, and $\mathrm{np}_{\mathrm{n}}$ values for Abu Dhabi

\begin{tabular}{|c|c|c|c|c|c|c|}
\hline \# & $\mathrm{DM}_{1}$ & $\mathrm{DM}_{2}$ & $\mathrm{DM}_{3}$ & Average Weights & PDA and NDA Values & $\mathrm{sp}_{\mathrm{n}}$ and $\mathrm{np}_{\mathrm{n}}$ \\
\hline $\mathrm{C}_{11}$ & $\mathrm{HI}$ & VHI & VHI & {$[(0.70 ; 0.81),(0.53 ; 0.64),(0.28 ; 0.39)]$} & $\begin{array}{l}{[(-0.15 ; 0.17),(0.78 ; 0.94),(-0.15 ; 0.16)]} \\
{[(-0.17 ; 0.15),(0.78 ; 0.94),(-0.16 ; 0.15)]}\end{array}$ & $\begin{array}{l}{[(-0.1 ; 0.14),(0.89 ; 0.98),(0.17 ; 0.49)]} \\
{[(-0.12 ; 0.12),(0.89 ; 0.98),(0.16 ; 0.48)]}\end{array}$ \\
\hline $\mathrm{C}_{12}$ & $\mathrm{HI}$ & $\mathrm{HI}$ & HI & {$[(0.63 ; 0.74),(0.46 ; 0.58),(0.35 ; 0.46)]$} & $\begin{array}{l}{[(-0.11 ; 0.19),(0.65 ; 0.82),(-0.17 ; 0.13)]} \\
{[(-0.19 ; 0.11),(0.65 ; 0.82),(-0.13 ; 0.17)]}\end{array}$ & $\begin{array}{l}{[(-0.18 ; 0.26),(0.72 ; 0.9),(0.04 ; 0.26)]} \\
{[(-0.25 ; 0.19),(0.72 ; 0.9),(0.04 ; 0.27)]}\end{array}$ \\
\hline $\mathrm{C}_{13}$ & AAI & AAI & HI & {$[(0.56 ; 0.67),(0.38 ; 0.49),(0.42 ; 0.54)]$} & $\begin{array}{l}{[(0.13 ; 0.43),(0.52 ; 0.67),(-0.41 ;-0.11)]} \\
{[(-0.43 ;-0.13),(0.52 ; 0.67),(0.11 ; 0.41)]}\end{array}$ & $\begin{array}{l}{[(-0.1 ; 0.47),(0.51 ; 0.75),(0.01 ; 0.13)]} \\
{[(-0.55 ; 0.12),(0.51 ; 0.75),(0.02 ; 0.19)]}\end{array}$ \\
\hline $\mathrm{C}_{14}$ & $\mathrm{HI}$ & $\mathrm{HI}$ & $\mathrm{HI}$ & {$[(0.63 ; 0.74),(0.46 ; 0.58),(0.35 ; 0.46)]$} & $\begin{array}{l}{[(-0.02 ; 0.27),(0.65 ; 0.82),(-0.26 ; 0.04)]} \\
{[(-0.27 ; 0.02),(0.65 ; 0.82),(-0.04 ; 0.26)]}\end{array}$ & $\begin{array}{l}{[(-0.11 ; 0.58),(0.41 ; 0.69),(0 ; 0.06)]} \\
{[(-0.82 ; 0.14),(0.41 ; 0.69),(0.01 ; 0.12)]}\end{array}$ \\
\hline $\mathrm{C}_{15}$ & LI & LI & LI & {$[(0.35 ; 0.46),(0.46 ; 0.58),(0.63 ; 0.74)]$} & $\begin{array}{l}{[(0.22 ; 0.62),(1.62 ; 1.87),(-0.72 ;-0.2)]} \\
{[(-0.62 ;-0.22),(1.62 ; 1.87),(0.2 ; 0.72)]}\end{array}$ & $\begin{array}{l}{[(-0.02 ; 0.7),(0.55 ; 0.95),(0 ; 0.04)]} \\
{[(-1.22 ; 0.05),(0.55 ; 0.95),(0 ; 0.11)]}\end{array}$ \\
\hline $\mathrm{C}_{16}$ & $\mathrm{HI}$ & AAI & AAI & {$[(0.57 ; 0.68),(0.39 ; 0.50),(0.41 ; 0.53)]$} & $\begin{array}{l}{[(-0.04 ; 0.25),(0.61 ; 0.75),(-0.24 ; 0.05)]} \\
{[(-0.25 ; 0.04),(0.61 ; 0.75),(-0.05 ; 0.24)]}\end{array}$ & $\begin{array}{l}{[(-0.05 ; 0.75),(0.42 ; 0.83),(0 ; 0.02)]} \\
{[(-1.53 ; 0.07),(0.42 ; 0.83),(0 ; 0.07)]}\end{array}$ \\
\hline $\mathrm{C}_{21}$ & AI & VHI & VHI & {$[(0.67 ; 0.77),(0.32 ; 0.45),(0.31 ; 0.41)]$} & $\begin{array}{l}{[(-0.1 ; 0.12),(0.41 ; 0.52),(-0.14 ; 0.07)]} \\
{[(-0.01 ; 0.1),(0.41 ; 0.52),(-0.07 ; 0.14)]}\end{array}$ & $\begin{array}{l}{[(-0.12 ; 0.77),(0.25 ; 0.61),(0 ; 0.01)]} \\
{[(-1.54 ; 0.14),(0.25 ; 0.61),(0 ; 0.03)]}\end{array}$ \\
\hline $\mathrm{C}_{22}$ & AI & VHI & $\mathrm{HI}$ & {$[(0.63 ; 0.73),(0.30 ; 0.43),(0.35 ; 0.45)]$} & $\begin{array}{l}{[(-0.28 ;-0.06),(0.31 ; 0.45),(0.03 ; 0.24)]} \\
{[(0.16 ; 0.28),(0.31 ; 0.45),(-0.24 ;-0.03)]}\end{array}$ & $\begin{array}{l}{[(-0.31 ; 0.76),(0.13 ; 0.42),(0 ; 0.01)]} \\
{[(-1.28 ; 0.32),(0.13 ; 0.42),(0 ; 0.01)]}\end{array}$ \\
\hline $\mathrm{C}_{23}$ & HI & VHI & VHI & {$[(0.70 ; 0.81),(0.53 ; 0.64),(0.28 ; 0.39)]$} & $\begin{array}{l}{[(-0.12 ; 0.19),(0.78 ; 0.94),(-0.2 ; 0.11)]} \\
{[(-0.02 ; 0.12),(0.78 ; 0.94),(-0.11 ; 0.2)]}\end{array}$ & $\begin{array}{l}{[(-0.42 ; 0.8),(0.12 ; 0.41),(0 ; 0)]} \\
{[(-1.32 ; 0.39),(0.12 ; 0.41),(0 ; 0.01)]}\end{array}$ \\
\hline $\mathrm{C}_{24}$ & LI & $\mathrm{HI}$ & VHI & {$[(0.58 ; 0.70),(0.49 ; 0.61),(0.40 ; 0.51)]$} & $\begin{array}{l}{[(-0.33 ; 0.03),(0.8 ; 0.99),(-0.04 ; 0.32)]} \\
{[(0.16 ; 0.33),(0.8 ; 0.99),(-0.32 ; 0.04)]}\end{array}$ & $\begin{array}{l}{[(-0.7 ; 0.81),(0.1 ; 0.41),(0 ; 0)]} \\
{[(-1.1 ; 0.53),(0.1 ; 0.41),(0 ; 0)]}\end{array}$ \\
\hline $\mathrm{C}_{25}$ & $\mathrm{AI}$ & AI & AI & {$[(0.52 ; 0.58),(0.13 ; 0.24),(0.46 ; 0.52)]$} & $\begin{array}{l}{[(-0.07 ; 0.06),(0.62 ; 0.72),(-0.12 ; 0.04)]} \\
{[(0 ; 0.07),(0.62 ; 0.72),(-0.04 ; 0.12)]}\end{array}$ & $\begin{array}{l}{[(-0.75 ; 0.81),(0.07 ; 0.32),(0 ; 0)]} \\
{[(-1.1 ; 0.55),(0.07 ; 0.32),(0 ; 0)]}\end{array}$ \\
\hline $\mathrm{C}_{26}$ & AI & AI & $\mathrm{AI}$ & {$[(0.52 ; 0.58),(0.13 ; 0.24),(0.46 ; 0.52)]$} & $\begin{array}{l}{[(-0.1 ; 0.03),(0.62 ; 0.72),(-0.09 ; 0.07)]} \\
{[(0.03 ; 0.1),(0.62 ; 0.72),(-0.07 ; 0.09)]}\end{array}$ & $\begin{array}{l}{[(-0.84 ; 0.81),(0.05 ; 0.25),(0 ; 0)]} \\
{[(-1.07 ; 0.57),(0.05 ; 0.25),(0 ; 0)]}\end{array}$ \\
\hline $\mathrm{C}_{27}$ & HI & HI & HI & {$[(0.63 ; 0.74),(0.46 ; 0.58),(0.35 ; 0.46)]$} & $\begin{array}{l}{[(-0.26 ; 0.04),(0.65 ; 0.82),(-0.05 ; 0.24)]} \\
{[(0.12 ; 0.26),(0.65 ; 0.82),(-0.24 ; 0.05)]}\end{array}$ & $\begin{array}{l}{[(-1.15 ; 0.82),(0.04 ; 0.23),(0 ; 0)]} \\
{[(-0.91 ; 0.65),(0.04 ; 0.23),(0 ; 0)]}\end{array}$ \\
\hline $\mathrm{C}_{31}$ & VHI & $\mathrm{HI}$ & VHI & {$[(0.71 ; 0.82),(0.54 ; 0.65),(0.27 ; 0.38)]$} & $\begin{array}{l}{[(-0.19 ; 0.13),(0.81 ; 0.98),(-0.11 ; 0.21)]} \\
{[(-0.13 ; 0.19),(0.81 ; 0.98),(-0.21 ; 0.11)]}\end{array}$ & $\begin{array}{l}{[(-1.44 ; 0.84),(0.03 ; 0.23),(0 ; 0)]} \\
{[(-1.08 ; 0.71),(0.03 ; 0.23),(0 ; 0)]}\end{array}$ \\
\hline $\mathrm{C}_{32}$ & HI & AI & $\mathrm{HI}$ & {$[(0.60 ; 0.70),(0.31 ; 0.45),(0.38 ; 0.48)]$} & $\begin{array}{l}{[(-0.17 ; 0.06),(0.63 ; 0.74),(-0.03 ; 0.19)]} \\
{[(-0.06 ; 0.17),(0.63 ; 0.74),(-0.19 ; 0.03)]}\end{array}$ & $\begin{array}{l}{[(-1.69 ; 0.85),(0.03 ; 0.2),(0 ; 0)]} \\
{[(-1.16 ; 0.74),(0.03 ; 0.2),(0 ; 0)]}\end{array}$ \\
\hline $\mathrm{C}_{33}$ & AI & AI & HI & {$[(0.56 ; 0.64),(0.19 ; 0.31),(0.42 ; 0.50)]$} & $\begin{array}{l}{[(-0.09 ; 0.08),(0.59 ; 0.69),(-0.05 ; 0.13)]} \\
{[(-0.08 ; 0.09),(0.59 ; 0.69),(-0.13 ; 0.05)]}\end{array}$ & $\begin{array}{l}{[(-1.82 ; 0.85),(0.02 ; 0.16),(0 ; 0)]} \\
{[(-1.25 ; 0.76),(0.02 ; 0.16),(0 ; 0)]}\end{array}$ \\
\hline $\mathrm{C}_{34}$ & HI & BAI & HI & {$[(0.59 ; 0.70),(0.42 ; 0.54),(0.39 ; 0.51)]$} & $\begin{array}{l}{[(-0.11 ; 0.19),(0.67 ; 0.81),(-0.18 ; 0.12)]} \\
{[(-0.19 ; 0.11),(0.67 ; 0.81),(-0.12 ; 0.18)]}\end{array}$ & $\begin{array}{l}{[(-2 ; 0.87),(0.01 ; 0.14),(0 ; 0)]} \\
{[(-1.51 ; 0.78),(0.01 ; 0.14),(0 ; 0)]}\end{array}$ \\
\hline $\mathrm{C}_{35}$ & VHI & AI & AAI & {$[(0.62 ; 0.73),(0.32 ; 0.45),(0.35 ; 0.46)]$} & $\begin{array}{l}{[(-0.2 ; 0.03),(0.6 ; 0.71),(-0.01 ; 0.21)]} \\
{[(-0.03 ; 0.2),(0.6 ; 0.71),(-0.21 ; 0.01)]}\end{array}$ & $\begin{array}{l}{[(-2.37 ; 0.88),(0.01 ; 0.12),(0 ; 0)]} \\
{[(-1.55 ; 0.81),(0.01 ; 0.12),(0 ; 0)]}\end{array}$ \\
\hline $\mathrm{C}_{36}$ & AI & AI & AI & {$[(0.52 ; 0.58),(0.13 ; 0.24),(0.46 ; 0.52)]$} & $\begin{array}{l}{[(0 ; 0.15),(0.54 ; 0.65),(-0.1 ; 0.06)]} \\
{[(-0.15 ; 0),(0.54 ; 0.65),(-0.06 ; 0.1)]}\end{array}$ & $\begin{array}{l}{[(-2.37 ; 0.89),(0.01 ; 0.09),(0 ; 0)]} \\
{[(-1.75 ; 0.81),(0.01 ; 0.09),(0 ; 0)]}\end{array}$ \\
\hline $\mathrm{C}_{37}$ & HI & $\mathrm{HI}$ & HI & {$[(0.63 ; 0.74),(0.46 ; 0.58),(0.35 ; 0.46)]$} & $\begin{array}{l}{[(-0.27 ; 0.03),(0.77 ; 0.91),(-0.01 ; 0.28)]} \\
{[(-0.03 ; 0.27),(0.77 ; 0.91),(-0.28 ; 0.01)]}\end{array}$ & $\begin{array}{l}{[(-2.94 ; 0.89),(0.01 ; 0.08),(0 ; 0)]} \\
{[(-1.8 ; 0.85),(0.01 ; 0.08),(0 ; 0)]}\end{array}$ \\
\hline $\mathrm{C}_{38}$ & BAI & BAI & BAI & {$[(0.46 ; 0.58),(0.35 ; 0.46),(0.52 ; 0.63)]$} & $\begin{array}{l}{[(0.11 ; 0.45),(0.69 ; 0.85),(-0.43 ;-0.11)]} \\
{[(-0.45 ;-0.11),(0.69 ; 0.85),(0.11 ; 0.43)]}\end{array}$ & $\begin{array}{l}{[(-2.74 ; 0.92),(0 ; 0.08),(0 ; 0)]} \\
{[(-2.37 ; 0.84),(0 ; 0.08),(0 ; 0)]}\end{array}$ \\
\hline $\mathrm{C}_{39}$ & VHI & AI & HI & {$[(0.65 ; 0.76),(0.35 ; 0.48),(0.33 ; 0.43)]$} & $\begin{array}{l}{[(-0.15 ; 0.08),(0.53 ; 0.64),(-0.06 ; 0.17)]} \\
{[(-0.08 ; 0.15),(0.53 ; 0.64),(-0.17 ; 0.06)]}\end{array}$ & $\begin{array}{l}{[(-3.11 ; 0.92),(0 ; 0.06),(0 ; 0)]} \\
{[(-2.55 ; 0.86),(0 ; 0.06),(0 ; 0)]}\end{array}$ \\
\hline $\mathrm{C}_{41}$ & $\mathrm{HI}$ & VHI & LI & {$[(0.61 ; 0.73),(0.49 ; 0.61),(0.37 ; 0.49)]$} & $\begin{array}{l}{[(-0.16 ; 0.18),(0.77 ; 0.95),(-0.17 ; 0.16)]} \\
{[(-0.18 ; 0.16),(0.77 ; 0.95),(-0.16 ; 0.17)]}\end{array}$ & $\begin{array}{l}{[(-3.51 ; 0.93),(0 ; 0.06),(0 ; 0)]} \\
{[(-2.94 ; 0.87),(0 ; 0.06),(0 ; 0)]}\end{array}$ \\
\hline $\mathrm{C}_{42}$ & HI & VHI & LI & {$[(0.61 ; 0.73),(0.49 ; 0.61),(0.37 ; 0.49)]$} & $\begin{array}{l}{[(-0.16 ; 0.18),(0.77 ; 0.95),(-0.17 ; 0.16)]} \\
{[(-0.18 ; 0.16),(0.77 ; 0.95),(-0.16 ; 0.17)]}\end{array}$ & $\begin{array}{l}{[(-3.95 ; 0.94),(0 ; 0.06),(0 ; 0)]} \\
{[(-3.38 ; 0.89),(0 ; 0.06),(0 ; 0)]}\end{array}$ \\
\hline $\mathrm{C}_{51}$ & CHI & CHI & $\mathrm{CHI}$ & {$[(0.85 ; 1.00),(0.69 ; 0.80),(0.08 ; 0.24)]$} & $\begin{array}{l}{[(-0.46 ; 0.05),(1.32 ; 1.54),(-0.01 ; 0.5)]} \\
{[(-0.05 ; 0.46),(1.32 ; 1.54),(-0.5 ; 0.01)]}\end{array}$ & $\begin{array}{l}{[(-5.86 ; 0.94),(0 ; 0.07),(0 ; 0)]} \\
{[(-3.55 ; 0.94),(0 ; 0.07),(0 ; 0)]}\end{array}$ \\
\hline $\mathrm{C}_{52}$ & AAI & AAI & AAI & {$[(0.52 ; 0.63),(0.35 ; 0.46),(0.46 ; 0.58)]$} & $\begin{array}{l}{[(0.18 ; 0.49),(0.48 ; 0.63),(-0.47 ;-0.16)]} \\
{[(-0.49 ;-0.18),(0.48 ; 0.63),(0.16 ; 0.47)]}\end{array}$ & $\begin{array}{l}{[(-5.21 ; 0.96),(0 ; 0.05),(0 ; 0)]} \\
{[(-4.71 ; 0.93),(0 ; 0.05),(0 ; 0)]}\end{array}$ \\
\hline $\mathrm{C}_{53}$ & VHI & VHI & VHI & {$[(0.74 ; 0.85),(0.58 ; 0.69),(0.24 ; 0.35)]$} & $\begin{array}{l}{[(-0.26 ; 0.07),(0.92 ; 1.09),(-0.05 ; 0.28)]} \\
{[(-0.07 ; 0.26),(0.92 ; 1.09),(-0.28 ; 0.05)]}\end{array}$ & $\begin{array}{l}{[(-6.42 ; 0.96),(0 ; 0.06),(0 ; 0)]} \\
{[(-5.01 ; 0.95),(0 ; 0.06),(0 ; 0)]}\end{array}$ \\
\hline
\end{tabular}


Author contributions MLD has constructed the research, stated the flow of the article, and done all numerical applications, while the BÖ contributed by investigating industry applications and literature.

Data availability Some data used in this article are subject to change based on experts' experience background. Data provided in Appendix would be enough for reader to overview the numerical analysis steps.

\section{Declarations}

Conflict of interest Authors declare that they have no competing interests and that they have not used any funding.

Open Access This article is licensed under a Creative Commons Attribution 4.0 International License, which permits use, sharing, adaptation, distribution and reproduction in any medium or format, as long as you give appropriate credit to the original author(s) and the source, provide a link to the Creative Commons licence, and indicate if changes were made. The images or other third party material in this article are included in the article's Creative Commons licence, unless indicated otherwise in a credit line to the material. If material is not included in the article's Creative Commons licence and your intended use is not permitted by statutory regulation or exceeds the permitted use, you will need to obtain permission directly from the copyright holder. To view a copy of this licence, visit http://creativecommons.org/licenses/by/4.0/.

\section{References}

1. Mentzer, J.T., DeWitt, W., Keebler, J.S., Min, S., Nix, N.W., Smith, C.D., Zacharia, Z.G.: Defining supply chain management. J. Bus. Logist. 22(2), 1-25 (2001)

2. Derman, A.: History of Warehousing, printed book. (2010)

3. Raut, R.D., Narkhede, B.E., Gardas, B.B., Raut, V.: Multi-criteria decision making approach: a sustainable warehouse location selection problem. Int. J. Manag. Concepts Philos. 10(3), 260-281 (2017)

4. Ashrafzadeh, M., Rafiei, F.M., Isfahani, N.M., Zare, Z.: Application of fuzzy TOPSIS method for the selection of warehouse location: a case study. Interdiscip. J. Contemp. Res. Bus. 3(9), 655-671 (2012)

5. Wang, L. and Zhang, Z.Y.: October. A research on related questions of Chinese food cold chain development. In 2008 International Conference on Management of e-Commerce and e-Government (pp. 18-21). IEEE (2008)

6. Stragas, N., Zeimpekis, V., Bourlakis, M., Vlachos, I.: Basic principles for effective warehousing and distribution of perishable goods in the urban environment: current status, advanced technologies and future trends. Intell. Agrifood Chains Netw. pp.39-65. (2011)

7. Chai, J., Liu, J.N., Xu, Z.: A rule-based group decision model for warehouse evaluation under interval-valued Intuitionistic fuzzy environments. Expert Syst. Appl. 40(6), 1959-1970 (2013)

8. Boltürk, E., Çevik Onar, S., Öztayşi, B., Kahraman, C., Goztepe, K.: Multi-attribute warehouse location selection in humanitarian logistics using hesitant fuzzy AHP. Int. J. Anal. Hierarchy Process 8(2), 271-298 (2016)

9. Dey, B., Bairagi, B., Sarkar, B., Sanyal, S.K.: Group heterogeneity in multi member decision making model with an application to warehouse location selection in a supply chain. Comput. Ind. Eng. 105, 101-122 (2017)

10. Dey, B., Bairagi, B., Sarkar, B., Sanyal, S.K.: Warehouse location selection by fuzzy multi-criteria decision making methodologies based on subjective and objective criteria. Int. J. Manag. Sci. Eng. Manag. 11(4), 262-278 (2016)

11. Roh, S.Y., Jang, H.M., Han, C.H.: Warehouse location decision factors in humanitarian relief logistics. Asian J. Shipp. Logist. 29(1), 103-120 (2013)

12. Dey, B., Bairagi, B., Sarkar, B., Sanyal, S.K.: A hybrid fuzzy technique for the selection of warehouse location in a supply chain under a utopian environment. Int. J. Manag. Sci. Eng. Manag. 8(4), 250-261 (2013)

13. Özcan, T., Çelebi, N., Esnaf, Ş: Comparative analysis of multicriteria decision making methodologies and implementation of a warehouse location selection problem. Expert Syst. Appl. 38(8), 9773-9779 (2011)

14. Singh, R.K., Chaudhary, N., Saxena, N.: Selection of warehouse location for a global supply chain: a case study. IIMB Manag. Rev. 30(4), 343-356 (2018)

15. Demirel, T., Demirel, N.Ç., Kahraman, C.: Multi-criteria warehouse location selection using Choquet integral. Expert Syst. Appl. 37(5), 3943-3952 (2010)

16. Beg, I., Rashid, T.: Multi-criteria of bike purchasing using fuzzy choquet integral. J. Fuzzy Math. 22(3), 677-694 (2012)

17. Auephanwiriyakul, S., Keller, J.M., Gader, P.D.: Generalized Choquet fuzzy integral fusion. Inform. Fusion 3(1), 69-85 (2002)

18. Kaboli, A., Aryanezhad, M.B., Shahanaghi, K. and Niroomand, I.: A new method for plant location selection problem: a fuzzy-AHP approach. In 2007 IEEE International Conference on Systems, Man and Cybernetics (pp. 582-586). IEEE (2007)

19. Chu, T.C.: Facility location selection using fuzzy TOPSIS under group decisions. Int. J. Uncertain. Fuzziness Knowl.-Based Syst. 10(06), 687-701 (2002)

20. Riaz, M., Çagman, N., Wali, N., Mushtaq, A.: Certain properties of soft multi-set topology with applications in multi-criteria decision making. Decis. Mak. Appl. Manag. Eng. 3(2), 70-96 (2020)

21. Puška, A., Stojanović, I., Maksimović, A.: Evaluation of sustainable rural tourism potential in Brcko district of Bosnia and Herzegovina using multi-criteria analysis. Operat. Res. Eng. Sci. Theory Appl. 2(2), 40-54 (2019)

22. Chakraborty, S., Chattopadhyay, R., Chakraborty, S.: An integrated D-MARCOS method for supplier selection in an iron and steel industry. Decis. Mak. Appl. Manag. Eng. 3(2), 49-69 (2020)

23. Velasquez, M., Hester, P.T.: An analysis of multi-criteria decision making methods. Int. J. Oper. Res. 10(2), 56-66 (2013)

24. Rodrigue, J.P., Comtois, C., Slack, B.: The geography of transport systems, 4th edn. Routledge, New York (2013)

25. Flores S.E.: Food Australia, printed book. (2007)

26. Kitinoja, L.: Use of cold chains for reducing food losses in developing countries. Population 6(123), 5-60 (2013)

27. Prakash, G., Renold, A.P., Venkatalakshmi, B.: RFID based mobile cold chain management system for warehousing. Procedia Eng. 38, 964-969 (2012)

28. Salin, V.: Global cold storage capacity report. Report for the International Association of Refrigerated Warehouses. IARW, Alexandria (2010)

29. James, S.J., James, C.J.F.R.I.: The food cold-chain and climate change. Food Res. Int. 43(7), 1944-1956 (2010)

30. Singh, R.P.: Benchmarking study of the refrigerated warehousing industry sector in California. Public interest energy research (PIER) program contract and research project reports. California Energy Commission, PIER Program, California (2008)

31. Jol, S., Kassianenko, A., Wszol, K., Oggel, J.: The Cold Chain, one link in Canada's food safety initiatives. Food Control 18(6), 713-715 (2007)

32. Banaz N.: Cold Chain Appliacations in Supply Chain and a Vehicle Routing Problem Solution. Graduate Dissertation, Sakarya University, Turkey (2019) 
33. Hamprecht, J., Corsten, D., Noll, M., Meier, E.: Controlling the sustainability of food supply chains. Supply Chain Manag. Int. J. 10(1), 7-10 (2005)

34. Zhang, G., Habenicht, W., Spieß, W.E.L.: Improving the structure of deep frozen and chilled food chain with tabu search procedure. J. Food Eng. 60(1), 67-79 (2003)

35. Singhal, R., Saksena, S.: Performance assessment of the storage and warehousing Industry in India. J. Ind. Stat. 6(1), 15-40 (2017)

36. Singh, R.K., Gunasekaran, A., Kumar, P.: Third party logistics (3PL) selection for cold chain management: a fuzzy AHP and fuzzy TOPSIS approach. Ann. Oper. Res. 267(1), 531-553 (2018)

37. Degirmenci, İT., Karayun, I., Akyildirim, O.O.: Cold chain logistics for frozen food at tourism destinations. J. Manag. Market. Logist. 4(2), 159-167 (2017)

38. Singh, A.K., Subramanian, N., Pawar, K.S., Bai, R.: Cold chain configuration design: location-allocation decision-making using coordination, value deterioration, and big data approximation. Ann. Oper. Res. 270(1), 433-457 (2018)

39. Zhang, Q., Zhang, K., Song, B.: The information construction of third-party warehousing in the cold chain logistics In LISS 2012, pp. 409-414. Springer, Berlin, Heidelberg, Berlin (2013)

40. Fredriksson, A., Liljestrand, K.: Capturing food logistics: a literature review and research agenda. Int. J. Log. Res. Appl. 18(1), 16-34 (2015)

41. Arduino, G., Carrillo Murillo, D., Parola, F.: Refrigerated container versus bulk: evidence from the banana cold chain. Marit. Policy Manag. 42(3), 228-245 (2015)

42. Turcu, C.: Sustainable radio frequency identification solutions. BoDBooks on Demand, Norderstedt (2010)

43. Bogataj, M., Bogataj, L., Vodopivec, R.: Stability of perishable goods in cold logistic chains. Int. J. Prod. Econ. 93, 345-356 (2005)

44. Sarisoy, G.: Gıdaların Soğuk Zincir Lojistigi. Graduate Thesis, Bahcesehir Universitesi, Istanbul (2011)

45. Subin, R., 2011. Country: India's cold chain industry. Indo-American Chamber of Commerce, available at https://www.iaccindia. com/userfiles/files/India's\%20Cold,20.

46. Lambert, D.M., Cooper, M.C.: Issues in supply chain management. Ind. Mark. Manage. 29(1), 65-83 (2000)

47. Aguezzoul, A.: A preliminary analysis on third-party logistics selection. In 7th International Meeting for Research in Logistics AVIGNON pp. 24-26 (2008)

48. Göl, H., Çatay, B.: Third-party logistics provider selection: insights from a Turkish automotive company. Supply Chain Manag. Int. J. (2007)

49. Zimmermann, H.J.: Fuzzy set theory-and its applications. Springer Science \& Business Media, Berlin (2011)

50. Zadeh, L.A.: Information and control. Fuzzy Sets 8(3), 338-353 (1965)

51. Zadeh, L.A.: The concept of a linguistic variable and its application to approximate reasoning-I. Inf. Sci. 8(3), 199-249 (1975)

52. Atanassov, K.: Intuitionistic Fuzzy Sets. Fuzzy Sets Syst. 20(1), 87-96 (1986)
53. Torra, V.: Hesitant fuzzy sets. Int. J. Intell. Syst. 25(6), 529-539 (2010)

54. Smarandache, F.: Neutrosophic set-a generalization of the intuitionistic fuzzy set. Int. J. Pure Appl. Math. 24(3), 287 (2005)

55. Ding, J., Bai, W., Zhang, C.: New multi-attribute decision making method with single-valued neutrosophic graphs. Int. J. Neutrosophic Sci. (IJNS) 11(2), 76-86 (2020)

56. Ashraf, S., Abdullah, S.: Decision support modeling for agriculture land selection based on sine trigonometric single valued neutrosophic information. Int. J. Neutrosophic Sci. (IJNS) 9(2), 60-73 (2020)

57. Keshavarz Ghorabaee, M., Zavadskas, E.K., Olfat, L., Turskis, Z.: Multi-criteria inventory classification using a new method of evaluation based on distance from average solution (EDAS). Informatica 26(3), 435-451 (2015)

58. Kahraman, C., Keshavarz Ghorabaee, M., Zavadskas, E.K., Cevik Onar, S., Yazdani, M., Oztaysi, B.: Intuitionistic fuzzy EDAS method: an application to solid waste disposal site selection. J. Environ. Eng. Landsc. Manag. 25(1), 1-12 (2017)

59. Deli, I.: Interval-valued neutrosophic soft sets and its decision making. Int. J. Mach. Learn. Cybern. 8(2), 665-676 (2017)

60. Karaşan, A., Kahraman, C.: A novel interval-valued neutrosophic EDAS method: prioritization of the United Nations national sustainable development goals. Soft. Comput. 22(15), 4891-4906 (2018)

61. Rivieccio, U.: Neutrosophic logics: prospects and problems. Fuzzy Sets Syst. 159(14), 1860-1868 (2008)

62. Karaşan, A., Kahraman, C., Boltürk, E.: Interval-valued neutrosophic EDAS method: an application to prioritization of social responsibility projects. In fuzzy multi-criteria decision-making using neutrosophic sets, pp. 455-485. Springer, Cham (2019)

63. Ghorabaee, M.K., Amiri, M., Zavadskas, E.K., Turskis, Z., Antucheviciene, J.: A new multi-criteria model based on interval type-2 fuzzy sets and EDAS method for supplier evaluation and order allocation with environmental considerations. Comput. Ind. Eng. 112, 156-174 (2017)

64. Grattan-Guinness, I.: Fuzzy membership mapped onto intervals and many-valued quantities. Math. Log. Q. 22(1), 149-160 (1976)

65. Sambuc, R.: Fonctions and floues: application a l'aide au diagnostic en pathologie thyroidienne (Doctoral dissertation, Faculté de Médecine de Marseille) (1975)

66. Jahn, K.U.: Intervall-wertige Mengen. Math. Nachr. 68(1), 115132 (1975)

67. Korpela, J., Tuominen, M.: A decision aid in warehouse site selection. Int. J. Prod. Econ. 45(1-3), 169-180 (1996)

Publisher's Note Springer Nature remains neutral with regard to jurisdictional claims in published maps and institutional affiliations. 